\title{
SOEP
}

SOEPpapers

SOEPpabers
on Multidisciplinary Panel Data Research

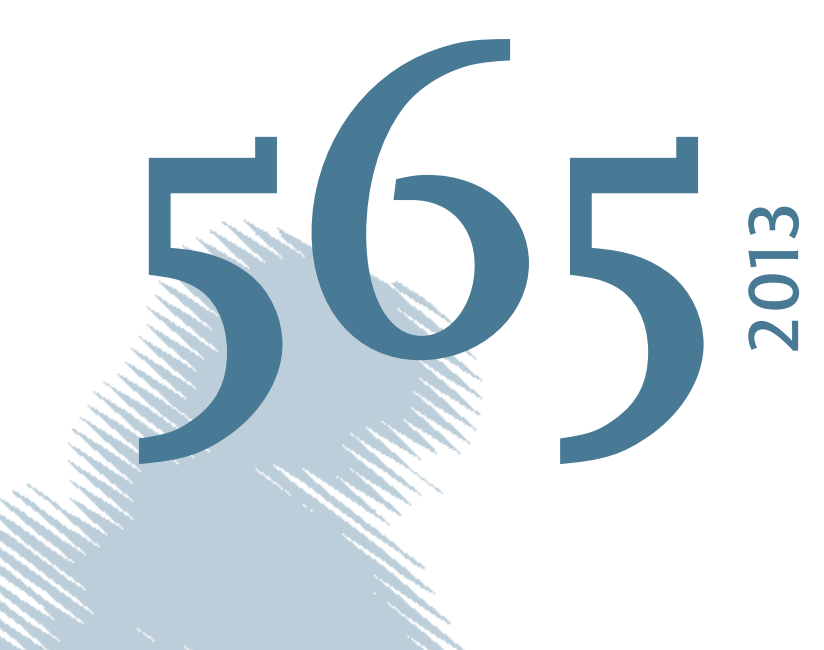

\section{Ethnic Concentration and Extreme Right-Wing Voting Behavior in West Germany}




\section{SOEPpapers on Multidisciplinary Panel Data Research}

at DIW Berlin

This series presents research findings based either directly on data from the German SocioEconomic Panel Study (SOEP) or using SOEP data as part of an internationally comparable data set (e.g. CNEF, ECHP, LIS, LWS, CHER/PACO). SOEP is a truly multidisciplinary household panel study covering a wide range of social and behavioral sciences: economics, sociology, psychology, survey methodology, econometrics and applied statistics, educational science, political science, public health, behavioral genetics, demography, geography, and sport science.

The decision to publish a submission in SOEPpapers is made by a board of editors chosen by the DIW Berlin to represent the wide range of disciplines covered by SOEP. There is no external referee process and papers are either accepted or rejected without revision. Papers appear in this series as works in progress and may also appear elsewhere. They often represent preliminary studies and are circulated to encourage discussion. Citation of such a paper should account for its provisional character. A revised version may be requested from the author directly.

Any opinions expressed in this series are those of the author(s) and not those of DIW Berlin. Research disseminated by DIW Berlin may include views on public policy issues, but the institute itself takes no institutional policy positions.

The SOEPpapers are available at

http://www.diw.de/soeppapers

\section{Editors:}

Jürgen Schupp (Sociology)

Gert G. Wagner (Social Sciences, Vice Dean DIW Graduate Center)

Conchita D'Ambrosio (Public Economics)

Denis Gerstorf (Psychology, DIW Research Director)

Elke Holst (Gender Studies, DIW Research Director)

Frauke Kreuter (Survey Methodology, DIW Research Professor)

Martin Kroh (Political Science and Survey Methodology)

Frieder R. Lang (Psychology, DIW Research Professor)

Henning Lohmann (Sociology, DIW Research Professor)

Jörg-Peter Schräpler (Survey Methodology, DIW Research Professor)

Thomas Siedler (Empirical Economics)

C. Katharina Spieß (Empirical Economics and Educational Science)

ISSN: 1864-6689 (online)

German Socio-Economic Panel Study (SOEP)

DIW Berlin

Mohrenstrasse 58

10117 Berlin, Germany

Contact: Uta Rahmann | soeppapers@diw.de 


\title{
Ethnic Concentration and
}

\section{Extreme Right-Wing Voting Behavior in West Germany}

\author{
Verena Dill \\ Department of Economics, University of Trier, Germany
}

June 2013

\begin{abstract}
Using data from the German Socio-Economic Panel (SOEP) and administrative data from 1996 to 2009, I investigate the question whether or not right-wing extremism of German residents is affected by the ethnic concentration of foreigners living in the same residential area. My results show a positive but insignificant relationship between ethnic concentration at county level and the probability of extreme right-wing voting behavior for West Germany. However, due to potential endogeneity issues, I additionally instrument the share of foreigners in a county with the share of foreigners in each federal state (following an approach of Dustmann/Preston 2001). I find evidence for the interethnic contact theory, predicting a negative relationship between foreigners' share and right-wing voting. Moreover, I analyze the moderating role of education and the influence of cultural traits on this relationship.
\end{abstract}

JEL: D72, R23, J15.

Keywords: Ethnic concentration, extreme right-wing voting, group threat, interethnic contact.

Address for correspondence: Verena Dill, University of Trier, Department of Economics, Labor Economics, Universitätsring 15, 54286 Trier, Germany, Email: dill@uni-trier.de.

This paper has benefited from valuable comments by participants of the IZA Annual Migration Meeting, the IZA European Summer School and the ESPE conference. In particular I am grateful to Uwe Jirjahn. All remaining errors are my own. 


\section{Introduction}

Tendencies of right-wing extremism in society have been always a serious concern, especially in Germany. Nowadays the public debate has reached a new point of intensity since in November 2011 it has been discovered that a number of eleven murders committed over the past ten years are linked to a right-wing extremist group. ${ }^{1}$ Due to these incidents and the associated investigations, politicians, as well as the public in Germany, started again to discuss the causes of right-wing extremism and the extent of hostile behavior by native German residents against foreigners.

One fact about the killings and right-wing extremism in general is quite striking: We observe that in regions with a comparably low share of foreigners a fertile breeding ground exists for right-wing extremist behavior. One may then ask if it is the low share of foreigners that strengthens prejudice and leads to hostile behavior. Or do confounding factors dominate this relationship? And to what extent does self-selection and sorting due to discrimination on the rental market play a role in determining the effect of foreigner share on hostile attitudes?

From a theoretical point, we can differentiate between two approaches that seek to explain hostile attitudes towards foreigners with respect to ethnic concentration: one is the group threat theory and the second is the interethnic contact theory. The group threat theory hypothesizes that individuals belonging to the majority group feel discarded as the relative number of minority group members increases and their perceived economic conditions deteriorate. A feeling of fear due to social and economic decline creates prejudice and hostile attitudes towards the minority group. Hence, a positive effect of ethnic concentration on hostile attitudes is expected (Sherif and Sherif 1953, Quillian 1995). In contrast to the group threat theory, the interethnic contact theory is based on the idea that a higher relative number of minority group members can help to overcome prejudice because of a higher frequency of contacts between the minority and majority 
group. If the interethnic contact theory explains hostile attitudes of German natives correctly then we would observe that negative attitudes are more likely in areas with fewer foreigners (Pettigrew 1986, Rothbart and John 1993).

In this paper, I seek to gain new insights into the causes of hostile attitudes expressed as extreme right-wing voting behavior in Germany. My paper contributes to a better understanding of this behavior in four ways. The first is methodological: Like some previous studies, I find that cross-sectional analyses point out a positive but insignificant relationship between the share of foreigners in a county and voting for a right-wing extremist party in West Germany. But in comparison to existing empirical studies, I additionally take into account that the effect of foreigner share on right-wing voting behavior might be endogenous. One of the reasons why the variable measuring the share of foreigners in a county is likely to be endogenous could be selfsorting of German natives and foreigners based on their voting behavior and/or sorting of foreigners in low-status neighborhoods due to discrimination on the housing market. To eliminate endogeneity I will estimate an instrumental variable equation which uses the share of foreigners on federal state level as an instrument following an approach of Dustmann and Preston (2001).

An additional source of endogeneity might be that the regional distribution of cultural traits is correlated with both the regional distribution of foreigners and hostile attitudes toward foreigners. ${ }^{2}$ If this holds true, variables that capture cultural traits must be included to avoid an omitted variable bias when estimating the effect of ethnic concentration on extreme right-wing voting. Hence, the second contribution of this paper is that it provides evidence whether or not deeply rooted prejudice passed down from generation to generation is the main factor which drives the endogeneity. For this purpose, I use a variety of variables that proxy cultural traits as controls in my regressions. It will be shown that, indeed, deeply rooted prejudices are positively correlated with the regional distribution of hostile attitudes towards foreigners but that these 
cultural traits are not the primary source of endogeneity.

Third, based on the rich information of the data used, I investigate the moderating role of education. Whether or not ethnic concentration has a uniform effect across the entire society is not clear at first sight. It could be assumed that especially low educated individuals tend to have xenophobic attitudes and therefore react differently to a certain ethnic concentration at the county level compared to respondents with a high educational attainment. To assess if education moderates the relationship between ethnic concentration and extreme right-wing voting, I run probit and instrumental variable estimations using subsamples based on individuals' educational attainment.

The fourth contribution is the analysis of socio-economic and locational variables that affect an individual's decision to vote for an extreme right-wing party in the recent years (from 1996 to 2009) using a large, representative data set for West Germany.

The main results of the paper are as follows. Using data from the German SocioEconomic Panel (SOEP), I find that simple probit estimates for West Germany show only insignificant results between ethnic concentration -measured as the share of foreigners at county level- and leaning towards an extreme right-wing party. But if the distribution of German residents and foreigners can be attributed to preferences for e.g. specific ethnic concentrations and/or to discrimination, the previous findings obtained by simple probit estimations would be biased. Thus, in a second step, I instrument the share of foreigners at county level with the share of foreigners at federal state level to address the endogeneity of this regressor. The results of the instrumental variable estimations show that the existence of a simultaneity bias cannot be rejected. Most interestingly, estimates are now highly significant and point out that the relationship is negative: A higher ethnic concentration is related to a lower probability of leaning towards an extreme right-wing party. In contrast to the simple probit estimation results, applying 
an instrumental variable approach provides support for the interethnic contact theory.

It stands to question what the driving factor of the endogeneity found in the instrumental variables estimates is. One factor can be analyzed directly from including variables that proxy the regional distribution of cultural traits (operationalized as pogroms in 1349 and as historical voting results during the Nazi-era) in the regressions. The results show that historical cultural traits explain today's right-wing extremist attitudes significantly and should be included as control variables. But I can rule out that these cultural traits are the primary source of endogeneity in this context. I conclude that self-sorting based on political voting behavior and/or discrimination on the housing market that forces foreigners to settle in socio-economic low regions are the main sources of endogeneity.

The hypothesis of a moderating role of education is supported for the group of individuals with an intermediate or a high educational attainment: For these subsamples I find that ethnic concentration affects extreme right-wing voting behavior negatively. Though, ethnic concentration does not play a role in predicting extreme right-wing views for individuals with a low education which might be due to two countervailing effects. On the one hand, Germans with a low education have a higher probability of leaning toward extreme right-wing parties because they are more likely to compete with foreigners for jobs, geographical or social welfare resources. On the other hand, the higher frequency of interactions between low-skilled Germans and low-skilled foreigners might help to overcome prejudice.

The rest of the paper is structured as follows. In section 2.1 the political system in Germany and its extreme right-wing parties are introduced briefly. Section 2.2 gives an overview of the existing empirical literature on hostile attitudes with particular emphasis on Germany. In Section 3 the different sources of endogeneity are explained. The possibility of heterogeneous effects with respect to individuals' educational attainment on attitudes towards foreigners is 
discussed in section 3.2. In section 4 I present the data sets and explain the two econometric models used. Results are discussed in Section 5. Section 6 sums up the main findings and concludes.

\section{Background Discussion}

\subsection{Institutional Setting - Right Wing Tendencies in Germany}

The political system in Germany is organized as a federal parliamentary republic. The federal legislative power is vested in the Bundestag (the parliament of Germany) and the Bundesrat (the representative body of the federal states of Germany). The Bundestag is directly elected by the German people every four years; the Bundesrat by state elections every five years. For the elections of 2009 for the Bundestag, the German citizens were able to choose from a range of 31 parties. $^{3}$

Based on the party's platform and its programmatic points, it is possible to locate parties on a continuum. Its two poles are the extreme left-wing and the extreme right-wing political attitudes. For instance, the German Communist Party (Deutsche Kommunistische Partei “DKP”) is located on the extreme left pole and parties like the German People's Union (Deutsche Volksunion "DVU”), the National Democratic Party of Germany (Nationaldemokratische Partei Deutschlands "NPD”) and the Republican Party ("Republikaner") are known to hold an extreme right-wing political view. Table 1 shows the results of the state elections of 2008/2009. The extreme right-wing parties reached a minimum of votes in Schleswig-Holstein and Hamburg $(0.9 \%)$ and a maximum of $6.1 \%$ in Mecklenburg-West Pomerania.

Besides these alarming electoral outcomes which are partly a result of a low voter turnout and so-called "protest votes", from the 1990s Germany experienced a number of tragic climaxes 
of right-wing motivated crimes. Here one has to mention the attacks on refugees and migrant workers homes' in Hoyerswerda, Schwedt, Eberswalde, Eisenhüttenstadt, Elsterwerder in 1991 and Rostock in 1992 (all cities situated in East Germany), attempted murders in Mölln in 1992 and Solingen in 1993 (West Germany) (Funke 1994). In most of these cases the police seemed not to do everything possible to protect those who were attacked which points to structural problems within the police force, the Ministry of the Interior and the Federal Office for the Protection of the Constitution in Germany.

In this paper, hostile attitudes towards foreigners are measured as a binary variable that takes the value of one if a respondent states to lean toward DVU, Republikaner or NPD, and zero otherwise. All three of the extreme right-wing parties are known for their ethnocentric, anticonstitutional and xenophobic party platforms that promote hostile attitudes towards foreigners (Rotte and Steininger 2008). Here the approach is to measure hostile attitudes of natives as leaning towards extreme right-wing parties which can be located as an intermediate expression of hostility against foreigners. ${ }^{4}$

\subsection{Related Literature}

From a methodical point of view, the existing literature on the relationship between ethnic concentration and attitudes towards foreigners can be divided into two different strands: The first group of studies uses ethnic concentration on a narrow level (e.g. perceived share of foreigners in the neighborhood or at county level) and treats it as an exogenous variable to examine the determinants of negative attitudes or crime against foreigners. The results of the international studies (with emphasis on the US) are mixed and differ by country, data set, and outcome variable used. Basically, the empirical evidence here is that ethnic concentration increases the probability of prejudice or hostile attitudes towards foreigners (Fossett and Kiecolt 1989, Glaser 
1994, Taylor 1998, Gang et al. 2002).

For Germany previous research shows also mixed results ranging from a significant positive effect of ethnic concentration on hostile attitudes to no effect. Lubbers and Scheepers (2001) investigate the reasons for extreme right-wing voting in Germany using an individualbased data set and show that ethnic concentration measured at federal state level explains this particular voting behavior positively. But this effect seems to be weak since it is significant only in one of their multi-level models. Another study that seeks to answer the question of how attitudes towards foreigners are formed by Fertig and Schmidt (2011) uses the ALLBUS 2006 which is a representative survey for Germany that covers a large set of questions regarding the perceptions of immigrants by Germans. They provide evidence that mainly education can explain the variation of perceptions of foreigners and Jews by German natives. Still, a higher share of foreigners increases significantly negative perceptions toward foreigners in some of their models.

A different but closely-related approach is pursued by Krueger and Pischke (1997): Instead of analyzing attitudes or perceptions towards foreigners, they go one step further and try to reveal the factors that can explain right-wing motivated crime against foreigners in Germany. Among other results, they show that the relative number of foreigners does not influence the number of ethnic crimes in West Germany, but in the East they provide evidence for a positive effect on the number of crimes per resident. In the same vein of providing evidence on the causes of right-wing extremist crime, Falk et al. (2011) use a data set from the German Federal Criminal Police Office and show that ethnic concentration at federal state level does not explain incidents of right-wing crime.

In contrast, Gang and Rivera-Batiz (1994) use data from the 1988 Eurobarometer and show that perceived high ethnic concentration of minorities in the neighborhood is related to more hostile attitudes of Germans. Finally, Weins (2011) aims at explaining the extent of 
prejudices by native German residents using the share of foreigners from 15 non-EU-states at county level. Her results show that a relationship between ethnic concentration and prejudice against foreigners exists as long as no controls for interethnic contacts are included.

One of the main caveats of the studies mentioned here is that they do not take into account that the share of foreigners or the variables measuring the frequency and intensity of direct contact to foreigners might be endogenous. Individuals may choose the place where to live for a variety of reasons: Proximity to family and friends, distance to their work place, or employment prospects. Besides these, individuals may base their locational choice on the share of foreigners in a neighborhood. Especially individuals who have hostile attitudes towards foreigners may prefer to live in neighborhoods with comparably less foreigners. In this case, the share of foreigners measured on a narrow level would not be exogenous with respect to one's attitudes towards foreigners. Thus, one of the main assumptions, namely that the error term is not correlated with the explanatory variables would be violated, which leads to inconsistent and biased estimates of the effect of ethnic concentration on attitudes.

Based on this argumentation, the second strand of literature addresses explicitly the issue of endogeneity. To my best knowledge the first study that exploits an instrumental variable approach to reduce a bias due to self-sorting is that of Dustmann and Preston (2001). Using several waves from the 1980s of the British Social Attitudes Survey, they investigate whether or not attitudes towards foreigners are driven by the ethnic concentration of a community. The crucial assumption Dustmann and Preston make use of is that self-sorting is likely to be limited to smaller areas. Natives may decide to live in a community with a low share of foreigners because they have prejudice against foreigners, but probably they will not adjust their location choices based on these attitudes on a larger spatial area. That is why they presume that instrumenting county level ethnic concentration with federal state ethnic concentration should reduce the bias. 
The results of their analysis suggest that self-sorting is an issue that diminishes the estimated effects of ethnic concentration on attitudes using simple probit estimation and that they can provide evidence for a positive relationship between these two variables.

In the light of these findings, a handful of studies emerged that also use an instrumental variable approach to reduce endogeneity. Bell et al. (2010) examine the relationship between the share of foreigners in a county and number of incidents of crime for Great Britain and find that the relative numbers of immigrants and property crimes are positively related even if they model endogeneity. Again for Great Britain, Lennox (2012) analyzes the determinants of British National Party (BNP) membership. He shows that the nonwhite population density is negatively associated with BNP-recruitment. He suggests that interethnic contact reduces prejudice and negative attitudes towards foreigners. In that sense, his study contradicts Dustmann and Preston (2001). But as Dustmann and Preston (2001, p.354) put it: "One should not necessarily expect consistency across studies using responses to different questions and data from different countries".

However, as far as Germany is concerned, the question to what extent ethnic concentration may explain right-wing voting behavior has not yet been investigated using an instrumental variable approach. This is the main contribution of the present paper because it would be of high interest for policy interventions that aim to reduce right-wing extremism to fully understand what causes right-wing extremism in Germany.

\section{The Relationship between Ethnic Concentration and Extreme Right-Wing Voting}

\subsection{The Issue of Endogeneity}

When estimating the relationship between ethnic concentration measured on a narrow spatial 
level and extreme right-wing voting, the issue of endogeneity due to several mechanisms may arise: First of all, self-sorting of foreigners as well as of German natives could lead to an underestimation of the effect. Germans that have racist sympathies might prefer to live in regions with a lower share of foreigners to minimize contact frequency with them. If, for example, the share of foreigners affects the probability of voting for the extreme right positive, using the share of foreigners at county level leads to an underestimation of the effect compared to a random sorting of German natives and foreigners. In the same vein, it can be assumed that foreigners decide to live in regions where they find more open-minded citizens with positive attitudes towards them. In this case, the non-random distribution leads to a downward bias of the estimated coefficient (Dustmann and Preston 2001).

Second, previous research has shown that foreigners in Germany tend to live in neighborhoods that have a lower environmental quality which can be attributed to different types of discrimination on the rental market (Dill and Jirjahn 2011; Dill et al. 2011). At the same time, low-status native German residents are also more likely to live in these neighborhoods. Foreigners as well as low-status Germans may then compete for housing and resources in general provided within the neighborhood. Since low-status individuals are believed to respond to stressful collective circumstances with hostile attitudes toward the minority group, it can be concluded that the effect of foreigner share on right-wing voting behavior would be overestimated (Oliver and Mendelberg 2000; Card et al. 2012).

Third, the distribution of culture traits may be associated with both the distribution of foreigners and with extreme right-wing voting behavior. Supposing that culture could be an omitted variable in this context is substantially motivated by a recent article and a discussion paper of Voigtländer and Voth (2012a, 2012b). Using hand-collected regional data on violence against Jews from medieval times they show that the geographical distribution cultural traits in medieval times can 
predict extreme right-wing tendencies and violence against Jews even in the 1920s and 1930s in Germany. Moreover, based on two waves (1996 and 2006) of the German General Social Survey they find that historical regional voting patterns for extreme right-wing parties between 1890 and 1933 are powerful predictors for anti-Jewish attitudes today. Based on these findings, it could be argued that the regional distribution of historical anti-Semitic views may have been perpetuated from generation to generation and may be positively (or negatively) associated to the distribution of foreigners in Germany. If this would be true, not controlling for the distribution of cultural traits would result in an overestimation (underestimation) of the effect. To analyze whether or not culture is the source of endogeneity, I include different variables that measure violence against Jews in medieval times and extreme right-wing voting behavior in the 1920s/30s (both at the county level). ${ }^{5}$

\subsection{The Moderating Role of Education}

Previous studies find that highly educated individuals are by far less likely to report xenophobic sentiments or hostile attitudes towards foreigners (Fertig and Schmidt 2011). Thus, it must be questioned if ethnic concentration triggers individual attitudes uniformly with respect to their educational attainment (Cornelißen and Jirjahn 2012, Schüller 2012). And furthermore, it can be assumed that the interaction of ethnic concentration and educational attainment affects the probability of voting for the extreme right differently with regard to different educational categories.

For example, it could be true that the share of foreigners in particular affects hostile attitudes of low-educated Germans positively. This psychological response may be the result of competition on the labor market since it is likely that this group of Germans competes for the same jobs in the

low-skilled segment of the labor market as foreigners do. ${ }^{6}$ Since the right-wing extremist parties 
explicitly present platforms that aim to defend the economic position of Germans (e.g. "Jobs for Nationals only"), voting for these parties might reflect to some extent the individual's exposure to competition on the labor market. Furthermore, the coincidence of low educated Germans and foreigners in socio-economic low neighborhoods could lead to competition for geographical resources like social services, housing and primary education. Again, voting for xenophobic parties may then be a response to stressful circumstances that Germans attribute to foreigners and competition for resources within the neighborhood.

Contrary to the previous reasoning which suggests a positive moderating effect between low education and ethnic concentration, one may also find arguments to predict a negative moderating of effect for the low educated: For example, it might be true that the higher contact frequency between low-skilled Germans and low-skilled foreigners helps to overcome antiforeigner sentiments. As co-workers both groups have a high frequency and intensity of contact with each other at least on a professional level which may lead to a better understanding and mutual respect.

At the higher end of the education distribution, education might have a liberalizing effect which could exert a moderating influence on the relationship between ethnic concentration and hostile attitudes (Arzheimer and Carter 2006): Specifically, higher secondary or tertiary education aims to develop an analytical and flexible thinking that helps to see through populist campaigns of the extreme right-wing parties and to value the advantages of living in areas with an ethnically mixed population. Moreover, Weil (1985) finds that not only formal education but ability itself predicts the probability of voting for the extreme right-wing parties very well. Which could also be true is that higher educated Germans consider immigrants on the labor market as complementary providing services to them (e.g. housekeepers) and not as substitutes. That is why they might regard the presence of a higher share of foreigners as economically beneficial. In the light of 
these arguments, I expect to find a negative effect of ethnic concentration on voting for extreme right-wing parties for the subsample highly educated individuals.

To investigate the moderating role of education I run probit estimations using subsamples of the German population based on low, medium and high educational attainment. I hypothesize that ethnic concentration has a different influence on the attitudes of Germans towards foreigners based on their educational level. Again, in a second step I will instrument the county level share of foreigners with the federal level share to get rid of a potential bias.

\section{Data, Econometric Modeling, and Descriptive Statistics}

\subsection{Data}

The data I use are drawn from the German Socio-Economic Panel (SOEP). The SOEP is a large representative longitudinal survey of randomly selected private households in Germany. It contains a broad range of questions which are asked every year (socio-economic indicators like education, age, income) as well as questions that appear only at intervals. Every household member above the age of 17 can participate in the survey (Wagner et al. 2007). Among others the respondents are asked to which political party they lean. A variety of parties are suggested in the questionnaire (SPD, CDU, CSU, FDP, Bündnis '90/Grüne, Die Linke, or DVU/ Republikaner/ NPD). ${ }^{7}$ Additionally, respondents are given the possibility to insert another party. Based on this question I created a binary variable that takes the value one if a respondent chooses DVU, Republikaner or NPD to be the party he is leaning the most toward, otherwise the variable is zero. Among other details, the SOEP provides information about the federal state, the regional policy region, and the county of residence. I use the latter to merge the socio-economic information provided by the SOEP with that from a second data set. The data are provided by the 
Statistical Office of Rhineland-Palatinate and contains information on the quantities of the native and foreign population on the level of official district codes (Kreiskennziffer "KKZ"). To generate the key explanatory variable (share of foreigners at county level) I merge the SOEP data set with the administrative data based on the recoded KKZ. ${ }^{8}$ Due to data privacy protection of the respondents, data at county level are only accessible via remote data processing ("soepremote") 9 . The share of foreigners at federal state level is based on the share at county level and thus a simple aggregation.

The third data source used here is provided by Voigtländer and Voth (2012a) and contains hand-collected regional data on violence against Jews from medieval times (dummy variable equals 1 if pogrom occurred in 1349, zero otherwise) as well as historical election outcomes (vote shares) from 1924 to 1933 for the Nazi parties. I merge this data at county level based on the information of the respondents' place of residence provided by the SOEP to control for the regional distribution of deep-rooted anti-foreigner sentiments in my regressions.

The purpose of this paper is to investigate political right-wing attitudes of German natives. Hence, the sample is restricted to respondents who have the German citizenship and do not have any migration background. ${ }^{10}$ Moreover, I only use observations from West Germany excluding the city-states Hamburg and Bremen. Compared to the other 7 federal states in West Germany, city-states cover only a comparably small, highly populated agglomeration area. With reference to the instrumental variable strategy these states had to be excluded. Using only West Germany is due to the facts that the number of observations for East Germany is comparably small and the variation of the share of foreigners is extremely low which make it impossible to apply the IV strategy to the East German sample. 


\subsection{Econometric Modeling}

First, basic probit estimations fitting a maximum likelihood function will be performed to investigate the relationship between ethnic concentration at county level and leaning towards an extreme right-wing party.

Let $y_{1 i}^{*}$ be the latent dependent variable that measures if respondent $i$ has hostile attitudes towards foreigners. Whether or not a person is hostile towards foreigners is affected by personal characteristics like education, income and age as well as by local features and economic conditions. The latent model can be written as

$$
y_{1 i}^{*}=\beta y_{2 i}+x_{2 i}^{\prime} \gamma+u_{i}
$$

where $y_{2 i}$ is share of foreigners at the county level and $x_{2}$ is a $1 \times k_{2}$ vector of exogenous variables. $\beta$ is the coefficient and $\gamma$ the coefficient vector of the latent model. The latent variable $y_{1 i}^{*}$ is unobserved. Rather, what can be observed is if respondent $i$ leans toward a right-wing extremist party (namely DVU, NPD or Republikaner). Consequently, the dependent variable takes the value 1 if a person leans toward a right-wing party and 0 otherwise:

$$
y_{1 i}= \begin{cases}0 & y_{1 i}^{*}<0 \\ 1 & y_{1 i}^{*} \geq 0\end{cases}
$$

The log likelihood function for the sample is given by

$$
\ln L=\sum_{i=1}^{N} y_{1 i} \ln \Phi\left(\beta y_{2 i}+\boldsymbol{x}_{2 i}^{\prime} \gamma\right)+\sum_{i=1}^{N}\left(1-y_{1 i}\right) \ln \left(1-\Phi\left(\beta y_{2 i}+\boldsymbol{x}_{2 i}^{\prime} \gamma\right)\right)
$$

As discussed before, potential endogeneity problems arise because of locational choices of Germans and foreigners, discrimination on the housing market, and the regional distribution of cultural traits. If one of these sources of endogeneity occurs, the variable that measures the share of foreigners at county level $y_{2 i}$ should not be treated as exogenous.

To overcome this bias I follow an approach suggested by Dustmann and Preston (2001). Note that the direction of the bias does not depend on the dominant hypothesis that explains 
hostile attitudes towards foreigners, even though group threat theory predicts a positive effect of ethnic concentration on right-wing voting whereas interethnic contact theory suggests a negative coefficient. It rather depends on the source of endogeneity that is present.

To start with the locational choices: If political attitudes influence location choices a negative correlation between $y_{2 i}$ and $u_{i}$ will be the result. The reason for this is that individuals who lean towards right-wing parties will probably choose a spatial area with a lower share of foreigners in comparison to individuals with more positive attitudes. Vice versa, foreigners may not settle in regions with a high degree of hostile attitudes towards them. Thus, the share of foreigners measured at the county level is not exogenous with respect to hostile attitudes towards foreigners $y_{1 i}^{*}$. In this case, estimating a simple probit model would yield inconsistent and downward biased estimates.

Secondly, discrimination on the rental market may be the driving factor of endogeneity which would result in an overestimation of the effect: It can be argued that foreigners may not choose to live in neighborhoods with a high degree of anti-foreigner sentiments but are forced to live there because of discrimination on the housing market (Dill and Jirjahn 2011; Dill et al. 2011). Rental companies and landlords may restrict foreigners to move into socio-economic high neighborhoods if they fear that an increasing share of foreigners reduces the willingness of tenants to pay high rents. Or it could be true that landlords themselves are prejudiced based on statistical discrimination: The average foreign tenant may have a higher probability of being an unreliable tenant in terms of payments, appropriate housing maintenance and compliance with house rules. Thus, the share of foreigners measured on a narrow level is not exogenous leading to an upward bias using a naïve estimation strategy.

Another source of endogeneity might be culture. The vast majority of foreigners arrived in Germany in the late 1950ies and during the 1960ies when the demand for workers was 
increasing substantially due to the booming economy. The German government started to arrange bilateral agreements with southern and south-eastern European countries to recruit so-called guest workers. It is noteworthy that the recruitment of guest workers was supposed to be temporary immigration, most of the guest workers were employed in low-skilled occupations in certain industries and were housed in barracks next to their work places. Even though the regional distribution of foreigners prior to 1973 (recruitment ban) was not driven by either positive or negative attitudes towards them but on labor shortages, one cannot rule out that they were placed in regions in post-war Germany with a high (low) degree of deep-rooted hostile attitudes towards foreigners. If these two distributions coincide positively (negatively) on a regional level given that regional mobility in Germany is rather low the effect of hostile attitudes towards foreigners will be overestimated (underestimated).

Instead of estimating simple probit models, consistent estimates can be obtained using an instrumental variable approach (Amemiya 1978, Rivers and Vuong 1988). The reduced form equation for $y_{2 i}$ is then given by

$$
y_{2 i}=x_{1 i} \Pi_{1}+x_{2 i}^{\prime} \Pi_{2}+\varepsilon_{i}
$$

where $y_{2 i}$ is the endogenous variable, $\boldsymbol{x}_{2}$ is a $1 \times k_{2}$ vector of exogenous variables, $x_{1}$ is an instrument that affects $y_{2 i}$ but can be excluded from (1). $x_{1}$ is assumed not to influence $y_{1 i}$ directly. $\Pi_{1}$ and $\Pi_{2}$ are matrices of reduced-form parameters and $\varepsilon_{i}$ an unobservable random error term. By assumption, the error terms of the two equations (1) and (4) are normally distributed with mean zero and variance $\Sigma:\left(u_{i}, \varepsilon_{i}\right) \sim \mathrm{N}(0 ; \Sigma)$. Since $y_{2 i}$ appears in the equation for $y_{1 i}^{*},(1)$, but $y_{1 i}^{*}$ does not appear in the equation for $y_{2 i},(4)$, it is a recursive model. The likelihood function is derived using the joint density $f\left(y_{1 i}, y_{2 i} \mid \boldsymbol{x}_{i}\right)$ as $f\left(y_{1 i} \mid y_{2 i}, \boldsymbol{x}_{i}\right) f\left(y_{2 i} \mid \boldsymbol{x}_{i}\right)$. When there is an endogenous regressor, the log likelihood for observation $i$ is 


$$
\ln L_{i}=y_{1 i} \ln \Phi\left(m_{i}\right)+\left(1-y_{1 i}\right) \ln \left\{1-\Phi\left(m_{i}\right)\right\}+\ln \phi\left(\frac{y_{2 i}-x_{1 i} \Pi_{1}-x_{2 i}^{\prime} \Pi_{2}}{\sigma}\right)-\ln \sigma
$$

where

$$
m_{i}=\frac{\left(\beta y_{2 i}+\boldsymbol{x}_{2 i}^{\prime} \gamma\right)+\rho\left(y_{2 i}-x_{1 i} \Pi_{1}-\boldsymbol{x}_{2 i}^{\prime} \Pi_{2}\right) / \sigma}{\left(1-\rho^{2}\right)^{1 / 2}}
$$

$\Phi(\cdot)$ and $\phi(\cdot)$ are the standard normal distribution and density functions, respectively; $\sigma$ is the standard deviation of $\varepsilon_{i} ; \rho$ is the correlation coefficient between $u_{i}$ and $\varepsilon_{i}$. If self-sorting based on political attitudes drives locational choices, $\rho$ can be either negative or positive.

\subsection{Key Variables}

Table 2 and 3 give an overview of the socio-economic characteristics of the respondents as well as descriptive statistics for the average share of foreigners at county level. The mean value for voting DVU, Republikaner or NPD is equal to 0.0072 , meaning that $0.72 \%$ of the respondents stated that they lean to an extreme right-wing party. The average share of foreigners at county level is $9.89 \%$. The county with the highest foreign population is "Rastatt" (BadenWuerttemberg). In Rastatt the share of foreigners equals $28.9 \%$. The county with the lowest share of foreigners is "Freyung-Grafenau" (Bavaria, 2.3\% foreigners).

To get a grip on the distribution of the dependent variable and the key explanatory variable, Fig. 1 (left hand side) shows the mean of voting for an extreme right-wing party averaged at county level for the years from 2005 to 2009. If one compares the distribution of right-wing voting to the share of foreigners at county level averaged for the years from 2005 to 2009 (right hand side of Fig. 1), it is noticeable that in regions with a lower share of foreigners individuals lean slightly more towards right-wing parties on average. This is especially striking for East Germany. For West Germany, a pattern can hardly be identified. Based on this graphical presentation of the dependent and the key explanatory variable, a negative relationship between 
share of foreigners at county level and right-wing voting behavior could be assumed. For the years 1996 to 2004 the distribution is similar but not displayed here.

\subsection{Control Variables}

Furthermore, I include several control variables in my estimations. Satisfaction with income is a subjective measure of the respondent's income on a scale ranging from 1 to 10 . I use this categorical variable rather than household income because I assume that negative attitudes towards foreigners are mainly driven by the perceived distributional income position and less by absolute income. The average satisfaction with one's income is 6.981 .

Related to factors that might affect attitudes because of a feeling of economic deprivation, I have added the county level unemployment rate to separate the effects of the key explanatory variable from other locational economic factors. Since immigrants tend to be highly concentrated in growing areas with good possibilities to work, not controlling for these effects might lead to a biased estimation of the variable representing the share of foreigners. In the sample, Eichstaett (Bavaria) has the lowest unemployment rate (1.9\%); Gelsenkirchen with a rate of 25.2 the highest.

Previous literature finds that education and ability are quite influential in explaining attitudes towards minorities (Fertig and Schmidt 2011). To control for this, I use the person's highest educational level (coded in three categories) and parental highest educational attainments (coded as a dummy that equals one if mother or father have a university degree). In my sample, roughly $14 \%$ have a low educational attainment, $54 \%$ an intermediate, and $32 \%$ can be classified as highly educated. Furthermore, $5.28 \%$ of the respondents have a mother with high education, $13.5 \%$ a highly educated father. Both, a person's education and their parental education are expected to affect right-wing voting behavior negatively (Weil 1985, Fertig and Schmidt 2011). 
To investigate the role of cultural traits, I use the historical voting results provided by Voigtländer and Voth (2012a). The descriptive statistics in Table 3 show the rise of the Naziparties during the 1920s to the 1930s in Germany. For example, in 1928 on average only $3.2 \%$ voted for the Nazi party NSDAP ("Nationalsozialistische Deutsche Arbeiterpartei"); in 1933 this number increased by a factor of almost 13 (40.7\% of the German population cast their vote to the NSDAP).

I have generated also dummy variables for the occupational status of the respondent. Different types of jobs might be affected differently by a high share of foreigners. For example, the influx of immigrants coming to Germany in the late 1960s consisted mostly of low skilled workers. Most of them were employed as semi-skilled or manual workers. Hence, Germans that have similar jobs are likely to face a higher labor market competition. If labor market competition or fear of unemployment influences right-wing voting behavior, I expect individuals belonging to relevant occupational categories to have a higher probability of voting for a right-wing party (Mayda 2006, Ortega and Polavieja 2012). The reason is that these parties mount regularly campaigns that stress job protection policies for natives (Rotte and Steininger 2008, Falk et al. 2011). Since especially unemployed respondents ( $2.45 \%$ of the sample) may perceive their labor market status as a result of crowding out by foreigners, I hypothesize that they also have a higher probability of voting for a right-wing party compared to the other occupational categories.

Moreover, I control for one's religion: I include a dummy variable that takes the value of one if a person is a Christian und zero if he/she is undenominational. $83 \%$ of the sample are Catholics and Protestants. Being Christian is expected to affect right-wing voting behavior negatively. The Church in Germany is engaged in a whole variety of activities that aim to help people in the rest of the world (e. g. "Bread for the world" - "Brot für die Welt" is one of the biggest programs initiated by the Protestant Church in Germany) and is involved in several 
projects that take a stand against right-wing extremism (e. g. "Church against right-wing extremism" - "Kirche gegen rechts"). That is why it can be concluded that a respondent that states to be a Christian (Catholic or Protestant) has a lower probability of voting for a right-wing party.

$73 \%$ of the respondents in the sample are married, $15 \%$ are single, $4 \%$ are divorced, and $8 \%$ are widowed. Marital status is also part of the control variable set on individual level since married respondents regularly share their income. Sharing income between household members is a way to lower volatility and uncertainty of income over time. Thus attitudes of married respondents may not be influenced by economic threats as much as those of singles. That is why married individuals are expected to report less hostile attitudes.

Furthermore, I include gender and the respondent's age in the set of control variables. Age is included as a continuous variable as well as its squared term divided by 100. Age is suspected to influence one's attitudes because "it maps the position of the individual in the economic cycle" especially with respect to employment (Dustmann and Preston 2001). That is why a humped-shaped relationship between age and voting for an extreme right-wing party can be expected. Besides this, being part of the German history during the years 1933 to 1945 is captured by this variable as well.

Being constantly exposed to many different ways of everyday living, requires more tolerance towards different cultures compared to people living in sparsely populated areas (Fossett and Kiecolt 1989, Dustmann and Preston 2001). To control for effects of urbanization on the dependent variable I include a set of 17 different categories that stem from the SOEP data. 


\section{Results}

This section presents the estimates of the simple probit model, the instrumental variable estimations, models that control for the regional distribution of cultural traits and estimations for subsamples based on education. All models include a set of basic individual controls, the type of settlement, and year dummies.

\subsection{Basic Estimates}

The first step of my analysis is the estimation of simple probit models. I am interested in the effect of ethnic concentration on individual attitudes towards foreigners. The dependent variable is measured as a binary variable that equals 1 if a person states to lean toward an extreme rightwing party (DVU, NPD or Republikaner) and 0 otherwise. Ethnic concentration is the share of foreigners at county level. Table 4 reports the coefficients for all regions situated in West Germany except for the city-states Hamburg and Bremen. The number of covariates is ascending from column (1) to (4). In all of the specifications it is shown that respondents who are more satisfied with their income are less likely to lean toward a right-wing extremist party. Women report a lower probability of voting for a right-wing party which is a standard finding in this strand of literature. As expected, the relationship between age and right-wing attitudes is humpshaped. Hence, the variables on age can be interpreted as capturing the life cycle of a person with special reference to employment prospects. In that sense, younger respondents show a lower probability of leaning towards right-wing parties. At a certain point in life this probability reaches a maximum but it declines as the person gets older. The marital status turns out to be insignificant in all specifications.

Another very typical hypothesis which has been investigated in the previous literature also holds true for this analysis: Column (2) shows that respondents with a low or intermediate 
educational attainment are significantly more likely to lean toward right-wing parties compared to respondents with a university degree. Moreover, the results show that being unemployed (reference group) is associated with a significant positive probability of voting for the right-wing compared to officers, white collar workers, persons in formal education, and non-working persons (column (3)). In column (4) variables capturing the religiousness of a respondent as well as the education level of the respondent's parents are included. Christians appear to have less prejudice against foreigners which seems to support the above reasoning that the German churches engage effectively against right-wing extremism. The dummy variables on father's and mother's education show evidence that has been reported in other studies before (e. g. Siedler 2011): High parental education lowers the probability of leaning toward a right-wing party which could capture that children who grow up with highly educated parents benefit from the liberalizing effect of education and/or that parental education proxies the cognitive skills of their children.

Besides these individual controls, one variable is included that describes a locational feature: The unemployment rate at county level is included in all regressions and turns out to be slightly negatively significant. Germans living in areas with a higher unemployment rate are less likely to vote for the extreme right. Among others, Arzheimer and Carter (2006) also find a similar effect and speculate that voters may prefer to cast their votes to the mainstream parties in times of economic uncertainty because these parties are more experienced and have better political and economic networks than the extreme right-wing parties.

In the probit estimations, presented as a first step, ethnic concentration at county level is treated as an exogenous regressor. The coefficient of the variable is positive but only slightly significant especially given the high number of observations (table 4). A higher concentration of foreigners at county level increases the probability of extreme right-wing voting behavior. 
Including different sets of control variables does not change the effect.

\subsection{Instrumental Variable Estimations}

In a second step, the instrumental variable approach suggested by Dustmann and Preston (2001) is used to explicitly take into account that the share of foreigners measured at county level may be endogenous for a variety of reasons.

To instrument the variable that measures ethnic concentration on a narrow level, I aggregate the share of foreigners at federal state level. Since individuals may exercise their location choices on a smaller spatial area, it is assumed that self-sorting based on attitudes towards foreigners at federal state level seems unlikely. The same holds for sorting due to discrimination: Here, I also assume that foreigners that are discriminated against by landlords may be forced to live in a socio-economic lower neighborhood but are unlikely to move from one federal state to another. Moreover, Voigtländer and Voth (2012a) show that the regional distribution of deeply rooted hostile attitudes proxied by the occurrence of pogroms in 1349 substantially varies at the regional level. Hence, instrumenting the share of foreigners on the federal state level also captures this source of endogeneity. Furthermore, I include different culture proxy variables as controls to rule out that culture is the omitted variable in my estimations.

From a theoretical point of view, I expect that the correlation between share of foreigners at county level and the share of foreigners at federal state level should be substantial. In order to provide evidence on the plausibility of the instrument, table 5 reports the $\mathrm{F}$ statistic of the excluded instrument. The instrument is highly correlated with the endogenous explanatory variable with an F statistic of 16.5. As suggested by Bound et al. (1995) an F statistic of 10 is the thumb-rule for a sufficient strong correlation with the endogenous explanatory variable. 
Table 5 shows the results of the instrumental variable estimations (ivprobit). Irrespective of the set of control variables used (columns (1) to (4)), the results reveal a significantly negative relationship between the share of foreigners and extreme right-wing voting behavior. The correlation between the error term on locational choice and right-wing voting (Rho) is positive and significant which points to the fact that the simple probit estimates involve a simultaneity bias. The effect is robust with reference to the assumed distribution since two-stage-least-squares yield similar results (not reported). Based on these findings it can be concluded that interethnic contact might be the source for extreme right-wing voting behavior in West Germany. To get a sense of the economic significance of the effect I computed projections that provide information about the probability of voting for an extreme right-wing party for different values of ethnic concentration (table 6). The projections show that the share of foreigners exerts a sizeable effect: For example, compared to a region with a share of foreigners equal to the mean $(0.235 \%$ probability to lean toward an extreme right-wing party), a region with a one standard deviation higher share of foreigners has a 0.204 percentage point (Difference of (2) 0.235 and (3) 0.031 in table (6)) lower probability to cast their vote to an extreme right-wing party.

\subsection{Culture as the Primary Source of Endogeneity}

Previous literature suggests that the regional distribution of cultural traits is a strong predictor for historical election results during the Nazi era and even for the distribution of current election results of extreme right-wing parties. In the last step of my analysis I include a variety of variables that proxy cultural traits. First, I use a dummy variable that indicates whether or not a pogrom between 1348 and 1350 has happened in a county. A pogrom is defined as systematical killing of Jewish inhabitants. Second, historical election results at county level from 1924 to 1933 measured as percentage of valid votes are included as controls. If culture is the primary source of 
endogeneity then even if a naïve probit procedure is used I would expect to obtain similar results like the ones I have found using the instrumental variable approach. If this is not the case, I would conclude that one or a combination of the different forms of (self-)sorting by German natives and foreigners into counties are the sources of endogeneity. To explore this possibility further, the cultural traits proxy variables are also included in the instrumental variable estimates.

Table 7 shows the probit estimates including a dummy variable indicating a pogrom in 1349 as well as historical election results for the Nazi-Party. Note that the historical data are only available for a subsample of West Germany. Hence, the number of observations is reduced compared to tables 2 to 6 . First of all, historical voting data affect right-wing voting behavior positively. In most of the cases this effect is quite substantial and significant (table 7, columns (4) to (8)) which supports the evidence provided by Voigtländer and Voth (2012b): The results show that cultural traits persist over a significant amount of time and can explain extreme right-wing attitudes even today. Second, ethnic concentration still does not explain leaning toward an extreme right-wing party significantly using the probit estimation technique. Moreover the sign is not reversed suggesting that cultural traits is not the primary source of endogeneity when estimating the relationship between ethnic concentration and extreme right-wing voting behavior. Furthermore, table (8) shows the instrumental variable probit results with inclusion of variables that capture cultural traits. Again, in most of the cases I find a negative and significant effect of ethnic concentration on extreme right-wing attitudes which supports the conclusion that the other above mentioned sources of endogeneity must be occurring when estimating this relationship.

\subsection{The Moderating Effect of Education}

Table 9 shows the results for low-, intermediate- and high-educated individuals respectively. The naïve probit estimates show very similar results compared to the probit estimates of table 4: For 
all of the three subsamples the coefficient of the share of foreigners measured at county level is positive and insignificant. The instrumental variable estimates differ substantially for individuals that attained an intermediate or high level of education: For both of the subsamples the effect of ethnic concentration now is negative and significant which is in line with the interethnic contact hypothesis (columns (2) and (3)). Moreover, it can be concluded that education helps to appreciate the benefits of an ethnically diverse society. Whether this is the result of either the liberalizing effect of education, cognitive skills or the perception that foreigners are complements on the labor market cannot be isolated with this data. ${ }^{11}$

For the group of low educated the effect of ethnic concentration is positive but insignificant (column (1)). I suspect that two effects might compensate each other leading to an insignificant coefficient: On the one hand, Germans with a low education have a higher probability of leaning towards one of the extreme right-wing parties because they are more likely to compete with foreigners for jobs, geographical resources (e.g. social services, housing, primary education) and/or social assistance provided by the state (e.g. unemployment benefits, social housing). Extreme right-wing parties in Germany pick up these economic based fears and promote party platforms that emphasize the prerogative of Germans with regard to these and other aspects. On the other hand, the higher frequency of interactions between low-skilled Germans and low-skilled foreigners at the work place or in neighborhoods might help to overcome prejudice. All in all, the results for the subsamples suggest that the negative effect for the full sample of observations is driven by educated persons which points to the fact that education is the main factor that triggers positive attitudes towards foreigners. 


\section{Summary and Conclusions}

In this paper, I investigate to what extent ethnic concentration influences hostile attitudes of German natives. Two theories can be applied to this question: On the one hand, group threat theory hypothesizes that a higher share of foreigners leads to a higher level of hostile attitudes. On the other hand, if interethnic theory predicts the relationship between ethnic concentration and hostile attitudes correctly, I expect that with an increasing share of foreigners the frequency of interethnic contacts will be higher and helps to overcome prejudice.

To address this question, I use data from the German Socio-Economic Panel (SOEP, waves from 1996 to 2009). The SOEP is a large, representative survey for Germany that contains also a question about the political attitudes of the respondents. To be more precise, I generate a binary variable that takes the value of 1 if a respondent states to lean toward a right-wing extremist party (DVU, NPD or Republikaner) and 0 otherwise. The SOEP consists also of information on the locality the respondent lives in. Based on this regional information, I merge the data of the SOEP with administrative data. The latter data set enables me to measure the ethnic concentration for each county in Germany. Moreover, I use historical data on violence against Jews in medieval times and election outcome during the Nazi-era at county level.

The empirical analysis is fourfold: First, I estimate simple probit models to examine the relationship between ethnic concentration measured at county level and extreme right-wing voting behavior. I find that ethnic concentration and extreme right-wing voting behavior are positively but insignificantly associated. However, results based on simple probit models should be viewed with caution. The reason is that ethnic concentration is likely to be endogenous for a variety of reasons. Thus, simple probit estimations may suffer from a simultaneity bias.

To overcome this bias, I follow an approach suggested by Dustmann and Preston (2001) and instrument the ethnic concentration at county level with an aggregated measure. The spatial 
level used to instrument ethnic concentration at county level is the ethnic concentration at federal state level. Using an instrumental variable procedure, I show that an endogeneity bias exists and that taking into account this endogeneity leads to a significant effect of ethnic concentration on extreme right-wing voting behavior. The effect of ethnic concentration on foreigners is now significantly negative and thus provides evidence for the interethnic contact theory.

Thirdly, I estimate probit models including historical voting results during the Nazi-era as well as a dummy variable at county level indicating whether a pogrom has taken place in medieval times. With this last step I want to examine if culture is the omitted variable causing the endogeneity found in the instrumental variable estimates. I find that most of the historical voting variables affect right-wing attitudes positively but are not the primary source of endogeneity.

In a forth step of the analysis, I assess whether or not a moderating role of education exists. My instrumental variables estimates show that for the subsample of intermediate- and high-educated Germans ethnic concentration is negatively associated with leaning toward an extreme right-wing party which points to a moderating role of education. For this subsample the results again support the interethnic contact theory. In contrast, the coefficient for the subsample of Germans with a low educational attainment is positive and insignificant. Here two countervailing effects might compensate each other leading to an insignificant result.

In conclusion, my results show that the issue of endogeneity should be taken seriously when examining the relationship between ethnic concentration and extreme right-wing voting behavior. With respect to the interethnic contact theory, for West Germany the results may suggest that policies which aim to reduce segregation and increase interethnic contact should be undertaken. 


\section{Figure 1: Share of Foreigners at County Level and Right-Wing Voting Behavior}
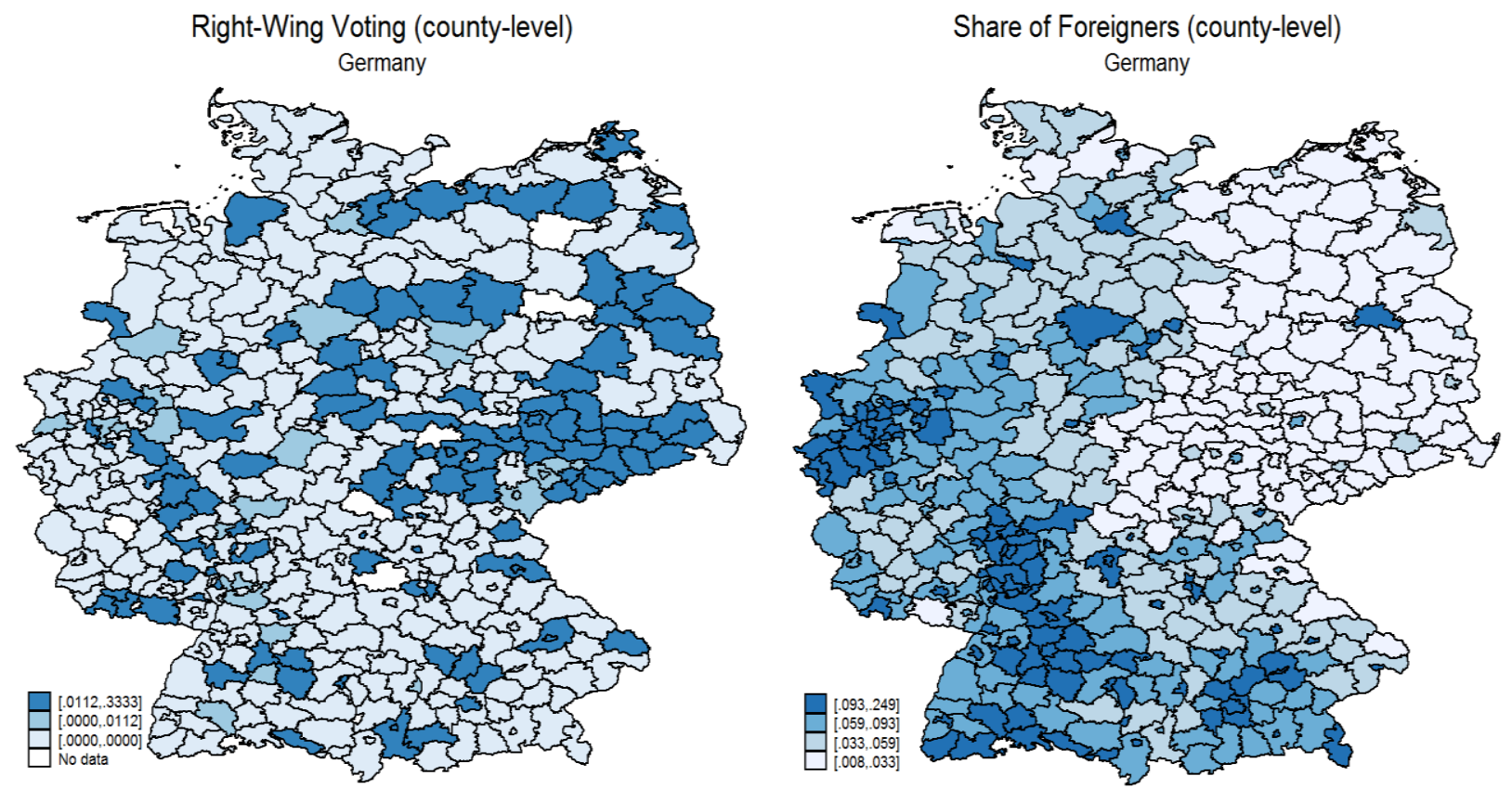

Source: SOEP (waves 1996-2009, version 27, doi:10.5684/soep.v27) and data provided by the Statistical Office of Rhineland-Palatinate, own calculations. 
Table 1: Results of State Elections for Extreme Right-Wing Parties 2008/2009

\begin{tabular}{llll}
\hline Federal state & $\begin{array}{l}\text { Total percent of voting for } \\
\text { right-wing parties }\end{array}$ & Federal state & $\begin{array}{l}\text { Total percent of voting for } \\
\text { right-wing parties }\end{array}$ \\
\hline Baden-Wuerttemberg & $2.1 \%$ & Lower Saxony & $1.5 \%$ \\
Bavaria & $2.6 \%$ & North Rhine-Westphalia & $1.0 \%$ \\
Berlin & $2.1 \%$ & Rhineland-Palatinate & $1.9 \%$ \\
Brandenburg & $2.8 \%$ & Saarland & $1.2 \%$ \\
Bremen & $1.6 \%$ & Saxony & $5.8 \%$ \\
Hamburg & $0.9 \%$ & Saxony-Anhalt & $4.6 \%$ \\
Hesse & $1.5 \%$ & Schleswig-Holstein & $0.9 \%$ \\
Mecklenburg-West Pomerania & $6.1 \%$ & Thuringia & $4.7 \%$ \\
\hline \hline
\end{tabular}

Note: Total percent of voting for right-wing parties is the sum of votes for NPD, DVU and Republikaner, respectively. Source: Ministry of the Interior of the Federal States. 
Table 2: Variable Description

\begin{tabular}{|c|c|}
\hline Variable & Description \\
\hline Right-wing voting & Dummy = 1 if respondent leans toward DVU, NPD or Republikaner. \\
\hline Share of foreigners at county level & Share of foreigners in a county in year $\mathrm{t}$. \\
\hline Share of foreigners at federal state level & Share of foreigners in a federal state in year $\mathrm{t}$. \\
\hline Pogrom 1349 & $\begin{array}{l}\text { Dummy }=1 \text { if a pogrom occurred in the years } 1348-50 \\
\text { (Voigtländer/Voth 2012a). }\end{array}$ \\
\hline DVFP vote, May 1924 & City-level DVFP vote, May 1924 (Voigtländer/Voth 2012a). \\
\hline DNVP vote, May 1924 & City-level DNVP vote, May 1924 (Voigtländer/Voth 2012a). \\
\hline NSDAP vote, May 1928 & City-level NSDAP vote, May 1928 (Voigtländer/Voth 2012a). \\
\hline NSDAP vote, September 1930 & City-level NSDAP vote, Sept 1930 (Voigtländer/Voth 2012a). \\
\hline NSDAP vote, July 1932 & City-level NSDAP vote, July 1932 (Voigtländer/Voth 2012a). \\
\hline NSDAP vote, November 1932 & City-level NSDAP vote, Nov 1932 (Voigtländer/Voth 2012a). \\
\hline NSDAP vote, March 1933 & City-level NSDAP vote, March 1933 (Voigtländer/Voth 2012a). \\
\hline Unemployment rate at county level & Unemployment rate at county level in percent. \\
\hline Satisfaction with income & Satisfaction with household income coded from 0 lowest to 10 highest. \\
\hline Female & Dummy $=1$ if respondent is a woman. \\
\hline Age & Age in years of respondent. \\
\hline $\operatorname{Age}^{2} / 100$ & Age in years of respondent squared and divided by 100 . \\
\hline Married & Dummy $=1$ if respondent is married. \\
\hline Divorced & Dummy $=1$ if respondent is divorced. \\
\hline Single (reference category) & Dummy $=1$ if respondent is single. \\
\hline Widowed & Dummy $=1$ if respondent is widowed. \\
\hline Low education & $\begin{array}{l}\text { Dummy }=1 \text { if respondent's highest educational attainment is secondary } \\
\text { education first stage. }\end{array}$ \\
\hline Intermediate education & $\begin{array}{l}\text { Dummy }=1 \text { if respondent's highest educational attainment is secondary } \\
\text { education second stage or a completed apprenticeship training. }\end{array}$ \\
\hline High education (reference category) & $\begin{array}{l}\text { Dummy }=1 \text { if respondent's highest educational attainment is first or } \\
\text { second stage of tertiary education. }\end{array}$ \\
\hline Not working & Dummy = 1 if respondent is not working. \\
\hline In formal education & Dummy $=1$ if respondent is in formal education/training. \\
\hline Unemployed (reference category) & Dummy = 1 if respondent is unemployed. \\
\hline Retired & Dummy $=1$ if respondent is retired. \\
\hline Civilian servant & Dummy = 1 if respondent is a civilian servant. \\
\hline In training & Dummy $=1$ if respondent is a trainee/intern. \\
\hline Manual worker & Dummy $=1$ if respondent is a manual worker. \\
\hline Farmer & Dummy $=1$ if respondent is a self-employed farmer. \\
\hline Self-employed & Dummy $=1$ if respondent is a self-employed person. \\
\hline White collar worker & Dummy $=1$ if respondent is a white collar worker. \\
\hline Officer & Dummy $=1$ if respondent is an officer. \\
\hline Christian & Dummy = 1 if respondent is protestant or catholic. \\
\hline $\begin{array}{l}\text { Undenominational or other religion } \\
\text { (reference category) }\end{array}$ & Dummy = 1 if respondent is undenominational or has other religion. \\
\hline Mother high education & $\begin{array}{l}\text { Dummy }=1 \text { if respondent's mother achieved first or second stage of } \\
\text { tertiary education. }\end{array}$ \\
\hline Father high education & $\begin{array}{l}\text { Dummy }=1 \text { if respondent's father achieved first or second stage of } \\
\text { tertiary education. }\end{array}$ \\
\hline Year dummies & Dummy variables for the years 1996 to 2009. \\
\hline Federal state dummies & Dummy variables for the federal states of Germany. \\
\hline
\end{tabular}

Source: SOEP (waves 1996-2009, version 27, doi:10.5684/soep.v27), data provided by the Statistical Office of Rhineland-Palatinate, and data provided by Voigtländer and Voth (2012a). 
Table 3: Summary Statistics - Full Sample $(N=47,509)$

\begin{tabular}{|c|c|c|c|c|}
\hline Variable & Mean & Minimum & Maximum & Std.-Dev. \\
\hline Right-wing voting & .0072 & 0 & 1 & .0844 \\
\hline Share of foreigners at county level & .0989 & .0233 & .2892 & .0498 \\
\hline Share of foreigners at federal state level & .0963 & .0511 & .1526 & .0301 \\
\hline Pogrom $1349^{+}$ & .6191 & 0 & 1 & .4856 \\
\hline DNVP vote, May $1924^{+}$ & .1261 & .0086 & .5202 & .0907 \\
\hline DVFP vote, May $1924^{+}$ & .0687 & .0010 & .4193 & .0738 \\
\hline NSDAP vote, May $1928^{+}$ & .0324 & .0025 & .2651 & .0354 \\
\hline NSDAP vote, September $1930^{+}$ & .1761 & .0254 & .4703 & .0779 \\
\hline NSDAP vote, July $1932^{+}$ & .3240 & .0985 & .6930 & .1030 \\
\hline NSDAP vote, November $1932^{+}$ & .2797 & .0692 & .6083 & .0896 \\
\hline NSDAP vote, March $1933^{+}$ & .4064 & .1557 & .7683 & .1046 \\
\hline Unemployment rate at county level & 9.084 & 1.9 & 25.2 & 3.168 \\
\hline Satisfaction with income & 6.981 & 0 & 10 & 2.071 \\
\hline Female & .4887 & 0 & 1 & .4999 \\
\hline Age & 52.34 & 17 & 99 & 15.86 \\
\hline $\operatorname{Age}^{2} / 100$ & 29.91 & 2.89 & 98.01 & 16.83 \\
\hline Married & .7302 & 0 & 1 & .4439 \\
\hline Divorced & .0401 & 0 & 1 & .1963 \\
\hline Single & .1523 & 0 & 1 & .3593 \\
\hline Widowed & .0774 & 0 & 1 & .2672 \\
\hline Low education & .1449 & 0 & 1 & .3520 \\
\hline Intermediate education & .5378 & 0 & 1 & .4986 \\
\hline High education & .3173 & 0 & 1 & .4654 \\
\hline Not working & .0891 & 0 & 1 & .2849 \\
\hline In formal education & .0198 & 0 & 1 & .1393 \\
\hline Unemployed & .0245 & 0 & 1 & .1547 \\
\hline Retired & .2950 & 0 & 1 & .4560 \\
\hline Civilian servant & .0022 & 0 & 1 & .0467 \\
\hline In training & .0094 & 0 & 1 & .0963 \\
\hline Manual worker & .0994 & 0 & 1 & .2992 \\
\hline Farmer & .0032 & 0 & 1 & .0561 \\
\hline Self-employed & .0506 & 0 & 1 & .2191 \\
\hline White collar worker & .3233 & 0 & 1 & .4678 \\
\hline Officer & .0778 & 0 & 1 & .2679 \\
\hline Christian & .8314 & 0 & 1 & .3744 \\
\hline Undenominational or other religion & .1582 & 0 & 1 & .3650 \\
\hline Other religion & .0104 & 0 & 1 & .1012 \\
\hline Mother high education & .1356 & 0 & 1 & .3424 \\
\hline Father high education & .0528 & 0 & 1 & .2237 \\
\hline
\end{tabular}

Note: Variables with the superscript "+" are only available for a subsample. For the size of the subsample please see table 7. Source: SOEP (waves 1996-2009, version 27, doi:10.5684/soep.v27), data provided by the Statistical Office of Rhineland-Palatinate, and data provided by Voigtländer and Voth (2012a), own calculations. 
Table 4: Probit Estimates - Step-by-Step inclusion of Variables

\begin{tabular}{|c|c|c|c|c|}
\hline & $\begin{array}{c}\text { (1) West Germany } \\
\text { excl. city-states }\end{array}$ & $\begin{array}{l}\text { (2) West Germany } \\
\text { excl. city-states }\end{array}$ & $\begin{array}{c}\text { (3) West Germany } \\
\text { excl. city-states }\end{array}$ & $\begin{array}{l}\text { (4) West Germany } \\
\text { excl. city-states }\end{array}$ \\
\hline $\begin{array}{l}\text { Share of foreigners at } \\
\text { county level }\end{array}$ & $\begin{array}{l}2.429 * \\
(1.461)\end{array}$ & $\begin{array}{l}2.608 * \\
(1.521)\end{array}$ & $\begin{array}{l}2.776^{*} \\
(1.583)\end{array}$ & $\begin{array}{c}2.369 \\
(1.580)\end{array}$ \\
\hline Satisfaction income & $\begin{array}{c}-.1331 * * * \\
(.0163)\end{array}$ & $\begin{array}{c}-.1248 * * * \\
(.0172)\end{array}$ & $\begin{array}{c}-.1171 * * * \\
(.0184)\end{array}$ & $\begin{array}{c}-.1153 * * * \\
(.0181)\end{array}$ \\
\hline Female & $\begin{array}{c}-.3033 * * * \\
(.0788)\end{array}$ & $\begin{array}{c}-.3594 * * * \\
(.0749)\end{array}$ & $\begin{array}{c}-.2603 * * * \\
(.0778)\end{array}$ & $\begin{array}{l}-.2316 * * * \\
(.0824)\end{array}$ \\
\hline Age & $\begin{array}{c}-.0695 * * * \\
(.0149)\end{array}$ & $\begin{array}{c}-.0521 * * * \\
(.0162)\end{array}$ & $\begin{array}{c}-.0666^{* * * *} \\
(.0165)\end{array}$ & $\begin{array}{c}-.0767 * * * \\
(.0168)\end{array}$ \\
\hline $\mathrm{Age}^{2} / 100$ & $\begin{array}{c}.0513 * * * \\
(.0133)\end{array}$ & $\begin{array}{c}.0331^{* * *} \\
(.0150)\end{array}$ & $\begin{array}{l}.0502 * * * \\
(.0151)\end{array}$ & $\begin{array}{l}.0609 * * * \\
(.0153)\end{array}$ \\
\hline Married & $\begin{array}{l}.0178 \\
(.1441)\end{array}$ & $\begin{array}{l}.0135 \\
(.1563)\end{array}$ & $\begin{array}{l}-.0279 \\
(.1530)\end{array}$ & $\begin{array}{l}-.0531 \\
(.1470)\end{array}$ \\
\hline Divorced & $\begin{array}{l}.1559 \\
(.1829)\end{array}$ & $\begin{array}{l}.1145 \\
(.1948)\end{array}$ & $\begin{array}{l}.0496 \\
(.1914)\end{array}$ & $\begin{array}{l}-.0259 \\
(.1877)\end{array}$ \\
\hline Widowed & $\begin{array}{l}-.2400 \\
(.3042)\end{array}$ & $\begin{array}{l}-.2912 \\
(.3137)\end{array}$ & $\begin{array}{l}-.4015 \\
(.3147)\end{array}$ & $\begin{array}{l}-.4428 \\
(.3176)\end{array}$ \\
\hline Unemployment rate & $\begin{array}{l}-.0238 \\
(.0166)\end{array}$ & $\begin{array}{l}-.0291 * \\
(.0168)\end{array}$ & $\begin{array}{l}-.0274 \\
(.0167)\end{array}$ & $\begin{array}{l}-.0263 * \\
(.0158)\end{array}$ \\
\hline Low education & --- & $\begin{array}{c}.8325^{* * *} \\
(.1381)\end{array}$ & $\begin{array}{c}.7671 * * * \\
(.1500)\end{array}$ & $\begin{array}{c}.7313 * * * \\
(.1530)\end{array}$ \\
\hline Intermediate education & --- & $\begin{array}{c}.5875^{* * * *} \\
(.1140)\end{array}$ & $\begin{array}{c}.4949 * * * \\
(.1136)\end{array}$ & $\begin{array}{c}.4763 * * * \\
(.1167)\end{array}$ \\
\hline Not working & --- & --- & $\begin{array}{c}-.4409 * * \\
(.1777)\end{array}$ & $\begin{array}{c}-.4108 * * \\
(.1858)\end{array}$ \\
\hline In formal education & --- & --- & $\begin{array}{c}-1.100 * * * \\
(.2510)\end{array}$ & $\begin{array}{l}-1.018 * * * \\
(.2574)\end{array}$ \\
\hline Retired & --- & --- & $\begin{array}{l}-.3212^{*} \\
(.1881)\end{array}$ & $\begin{array}{r}-.3233^{*} \\
(.1960)\end{array}$ \\
\hline Civilian Servant & --- & --- & $\begin{array}{l}-.3341 \\
(.2791)\end{array}$ & $\begin{array}{l}-.2763 \\
(.2833)\end{array}$ \\
\hline In training & --- & --- & $\begin{array}{l}-.0718 \\
(.1590)\end{array}$ & $\begin{array}{l}-.0174 \\
(.1613)\end{array}$ \\
\hline Manual worker & --- & --- & $\begin{array}{l}.1521 \\
(.1260)\end{array}$ & $\begin{array}{l}.1531 \\
(.1300)\end{array}$ \\
\hline Farmer & --- & --- & $\begin{array}{c}.2847 \\
(.4188)\end{array}$ & $\begin{array}{l}.4189 \\
(.4243)\end{array}$ \\
\hline Self-employed & --- & --- & $\begin{array}{l}-.2771 \\
(.1759)\end{array}$ & $\begin{array}{l}-.2545 \\
(.1792)\end{array}$ \\
\hline White collar worker & --- & --- & $\begin{array}{c}-.2705 * * \\
(.1273)\end{array}$ & $\begin{array}{c}-.2817 * * \\
(.1322)\end{array}$ \\
\hline Officer & --- & --- & $\begin{array}{l}-.7905 * * * \\
(.2425)\end{array}$ & $\begin{array}{c}-.8387 * * * \\
(.2504)\end{array}$ \\
\hline
\end{tabular}


Table 4: Probit Estimates - Step-by-Step inclusion of Variables (continued)

\begin{tabular}{lcccc}
\hline & $\begin{array}{c}\text { (1) West Germany } \\
\text { excl. city-states }\end{array}$ & $\begin{array}{c}\text { (2) West Germany } \\
\text { excl. city-states }\end{array}$ & $\begin{array}{c}\text { (3) West Germany } \\
\text { excl. city-states }\end{array}$ & $\begin{array}{c}\text { (4) West Germany } \\
\text { excl. city-states }\end{array}$ \\
\hline Christian & --- & --- & --- & $-.4792^{* * *}$ \\
& & & & $(.1115)$ \\
Father high education & --- & --- & $-.3381^{*}$ \\
& & & $-1839)$ \\
Mother high education & --- & --- & $-.4920^{*}$ \\
Constant & .3717 & -.4898 & --- & $.2515)$ \\
\hline Log pseudolikelihood & $(.5200)$ & $(.5361)$ & -.0814 & $(.5570$ \\
\hline Observations & -1654.07 & -1597.85 & -1531.13 & -1480.86 \\
\hline \hline
\end{tabular}

Note: All regressions include controls for type of settlement (17 types) and years (1996-2009). Reference category of qualitative variables: single, high education, unemployed, father has intermediate/low education, mother has intermediate/low education, undenominational/other religion. The table shows the estimated coefficients. Huber-White standard errors clustered at county level are in parentheses. *** Statistically significant at the $1 \%$ level; ** at the 5\% level; * at the 10\% level. Source: SOEP (waves 1996-2009, version 27, doi:10.5684/soep.v27), data provided by the Statistical Office of Rhineland-Palatinate, own calculations. 
Table 5: IV-Probit Estimates - Step-by-Step inclusion of Variables

\begin{tabular}{|c|c|c|c|c|}
\hline & $\begin{array}{c}\text { (1) West Germany } \\
\text { excl. city-states }\end{array}$ & $\begin{array}{c}\text { (2) West Germany } \\
\text { excl. city-states }\end{array}$ & $\begin{array}{c}\text { (3) West Germany } \\
\text { excl. city-states }\end{array}$ & $\begin{array}{c}\text { (4) West Germany } \\
\text { excl. city-states }\end{array}$ \\
\hline $\begin{array}{l}\text { Share of foreigners at } \\
\text { county level instrumented }\end{array}$ & $\begin{array}{l}-13.65 * * \\
(5.701)\end{array}$ & $\begin{array}{c}-13.94 * * \\
(5.697)\end{array}$ & $\begin{array}{c}-13.87 * * \\
(5.722)\end{array}$ & $\begin{array}{l}-12.01 * * \\
(5.647)\end{array}$ \\
\hline Satisfaction income & $\begin{array}{c}-.1222 * * * \\
(.0153)\end{array}$ & $\begin{array}{c}-.1138 * * * \\
(.0160)\end{array}$ & $\begin{array}{c}-.1066^{* * *} \\
(.0165)\end{array}$ & $\begin{array}{c}-.1077 * * * \\
(.0163)\end{array}$ \\
\hline Female & $\begin{array}{c}-.2676 * * * \\
(.0743)\end{array}$ & $\begin{array}{c}-.3192 * * * \\
(.0727)\end{array}$ & $\begin{array}{c}-.2270 * * * \\
(.0739)\end{array}$ & $\begin{array}{c}-.2069 * * * \\
(.0786)\end{array}$ \\
\hline Age & $\begin{array}{c}-.0602 * * * \\
(.0144)\end{array}$ & $\begin{array}{c}-.0441 * * * \\
(.0151)\end{array}$ & $\begin{array}{l}-.0561^{* * *} \\
(.0158)\end{array}$ & $\begin{array}{c}-.0674 * * * \\
(.0163)\end{array}$ \\
\hline $\mathrm{Age}^{2} / 100$ & $\begin{array}{c}.0444 * * * \\
(.0127)\end{array}$ & $\begin{array}{c}.0277 * * * \\
(.0138)\end{array}$ & $\begin{array}{c}.0419 * * * \\
(.0145)\end{array}$ & $\begin{array}{c}.0533 * * * \\
(.0148)\end{array}$ \\
\hline Married & $\begin{array}{l}-.0399 \\
(.1309)\end{array}$ & $\begin{array}{l}-.0459 \\
(.1412)\end{array}$ & $\begin{array}{l}-.0763 \\
(.1372)\end{array}$ & $\begin{array}{l}-.0953 \\
(.1368)\end{array}$ \\
\hline Divorced & $\begin{array}{l}.0987 \\
(.1666)\end{array}$ & $\begin{array}{l}.0607 \\
(.1766)\end{array}$ & $\begin{array}{l}.0003 \\
(.1736)\end{array}$ & $\begin{array}{l}-.0651 \\
(.1755)\end{array}$ \\
\hline Widowed & $\begin{array}{l}-.3057 \\
(.2783)\end{array}$ & $\begin{array}{l}-.3541 \\
(.2840)\end{array}$ & $\begin{array}{l}-.4490 \\
(.2845)\end{array}$ & $\begin{array}{l}-.4859 \\
(.2953)\end{array}$ \\
\hline Unemployment rate & $\begin{array}{c}-.0907 * * * \\
(.0334)\end{array}$ & $\begin{array}{c}-.0976^{* * * *} \\
(.0330)\end{array}$ & $\begin{array}{c}-.0962 * * * \\
(.0329)\end{array}$ & $\begin{array}{c}-.0871 * * * \\
(.0312)\end{array}$ \\
\hline Low education & --- & $\begin{array}{c}.7564 * * * \\
(.1449)\end{array}$ & $\begin{array}{c}.7079 * * * \\
(.1498)\end{array}$ & $\begin{array}{l}.6918 * * * \\
(.1537)\end{array}$ \\
\hline Intermediate education & --- & $\begin{array}{l}.5463 * * * \\
(.1097)\end{array}$ & $\begin{array}{c}.4622 * * * \\
(.1075)\end{array}$ & $\begin{array}{l}.4600 * * * \\
(.1120)\end{array}$ \\
\hline Not working & --- & --- & $\begin{array}{c}-.4114 * * \\
(.1687)\end{array}$ & $\begin{array}{c}-.3897 * * \\
(.1783)\end{array}$ \\
\hline In formal education & --- & --- & $\begin{array}{l}-.9559 * * * \\
(.2473)\end{array}$ & $\begin{array}{l}-.9088 * * * \\
(.2515)\end{array}$ \\
\hline Retired & --- & --- & $\begin{array}{l}-.2582 \\
(.1796)\end{array}$ & $\begin{array}{l}-.2734 \\
(.1892)\end{array}$ \\
\hline Civilian Servant & --- & --- & $\begin{array}{l}-.3271 \\
(.2734)\end{array}$ & $\begin{array}{l}-.2828 \\
(.2797)\end{array}$ \\
\hline In training & --- & --- & $\begin{array}{l}-.0407 \\
(.1468)\end{array}$ & $\begin{array}{c}.0057 \\
(.1515)\end{array}$ \\
\hline Manual worker & --- & --- & $\begin{array}{l}.14571 \\
(.1119)\end{array}$ & $\begin{array}{l}.1527 \\
(.1193)\end{array}$ \\
\hline Farmer & --- & --- & $\begin{array}{l}.4368 \\
(.3600)\end{array}$ & $\begin{array}{l}.5439 \\
(.3771)\end{array}$ \\
\hline Self-employed & --- & --- & $\begin{array}{l}-.2348 \\
(.1639)\end{array}$ & $\begin{array}{l}-.2246 \\
(.1697)\end{array}$ \\
\hline White collar worker & --- & --- & $\begin{array}{l}-.2092^{*} \\
(.1237)\end{array}$ & $\begin{array}{l}-.2308^{*} \\
(.1302)\end{array}$ \\
\hline Officer & --- & --- & $\begin{array}{l}-.7459 * * * \\
(.2264)\end{array}$ & $\begin{array}{l}-.7994 * * * \\
(.2383)\end{array}$ \\
\hline
\end{tabular}


Table 5: IV-Probit Estimates - Step-by-Step inclusion of Variables (continued)

\begin{tabular}{|c|c|c|c|c|}
\hline & $\begin{array}{l}\text { (1) West Germany } \\
\text { excl. city-states }\end{array}$ & $\begin{array}{l}\text { (2) West Germany } \\
\text { excl. city-states }\end{array}$ & $\begin{array}{l}\text { (3) West Germany } \\
\text { excl. city-states }\end{array}$ & $\begin{array}{l}\text { (4) West Germany } \\
\text { excl. city-states }\end{array}$ \\
\hline Christian & --- & --- & --- & $\begin{array}{c}-.4502 * * * \\
(.1034)\end{array}$ \\
\hline Father high education & --- & --- & --- & $\begin{array}{l}-.2888^{*} \\
(.1702)\end{array}$ \\
\hline Mother high education & --- & --- & --- & $\begin{array}{l}-.4460^{*} \\
(.2318)\end{array}$ \\
\hline Constant & $\begin{array}{l}1.432 * * \\
(.6287)\end{array}$ & $\begin{array}{c}.6748 \\
(.6748) \\
\end{array}$ & $\begin{array}{c}.9966 \\
(.6500)\end{array}$ & $\begin{array}{l}1.445^{* *} \\
(.6637)\end{array}$ \\
\hline Rho & $\begin{array}{c}.4616 * * * \\
(.1764)\end{array}$ & $\begin{array}{c}.4769 * * * \\
(.1784)\end{array}$ & $\begin{array}{c}.4774 * * * \\
(.1788)\end{array}$ & $\begin{array}{l}.4073^{* *} \\
(.1688)\end{array}$ \\
\hline F-Value & $16.41 * * *$ & $16.46 * * *$ & $16.53 * * *$ & $16.55 * * *$ \\
\hline Log pseudolikelihood & 105678.24 & 105740.33 & 105856.21 & 105922.60 \\
\hline Observations & 47509 & 47509 & 47509 & 47509 \\
\hline
\end{tabular}

Note: All regressions include controls for type of settlement (17 types) and years (1996-2009). Reference category of qualitative variables: single, high education, unemployed, father has intermediate/low education, mother has intermediate/low education, undenominational/other religion. The table shows the estimated coefficients. Huber-White standard errors clustered at county level are in parentheses. *** Statistically significant at the $1 \%$ level; ** at the 5\% level; * at the $10 \%$ level. F-Value obtained from first-stage regression. Source: SOEP (waves 1996-2009, version 27, doi:10.5684/soep.v27), data provided by the Statistical Office of Rhineland-Palatinate, own calculations. 


\section{Table 6: Projected Influence of Ethnic Concentration on Voting for Extreme Right-Wing Parties}

\begin{tabular}{lcccc}
\hline & $\begin{array}{c}\text { (1) Share of } \\
\text { foreigners equals } \\
\text { the sample's mean } \\
\text { minus one standard } \\
\text { deviation }\end{array}$ & $\begin{array}{c}\text { (2) Share of } \\
\text { foreigners equals } \\
\text { the sample's mean }\end{array}$ & $\begin{array}{c}\text { (3) Share of } \\
\text { foreigners equals } \\
\text { the sample's mean } \\
\text { plus one standard } \\
\text { deviation }\end{array}$ & $\begin{array}{c}\text { (4) Share of } \\
\text { foreigners equals } \\
\text { the sample's mean } \\
\text { plus two standard } \\
\text { deviation }\end{array}$ \\
\hline $\begin{array}{l}\text { Probability of voting } \\
\text { for extreme right-wing } \\
\text { parties in percentage }\end{array}$ & 1.290 & 0.235 & 0.031 & 0.003 \\
\hline \hline
\end{tabular}

The projections are based on estimation (4) in table 5. Source: SOEP (waves 1996-2009, version 27, doi:10.5684/soep.v27), data provided by the Statistical Office of Rhineland-Palatinate, own calculations. 
Table 7: Probit Estimates - Controlling for Cultural Traits

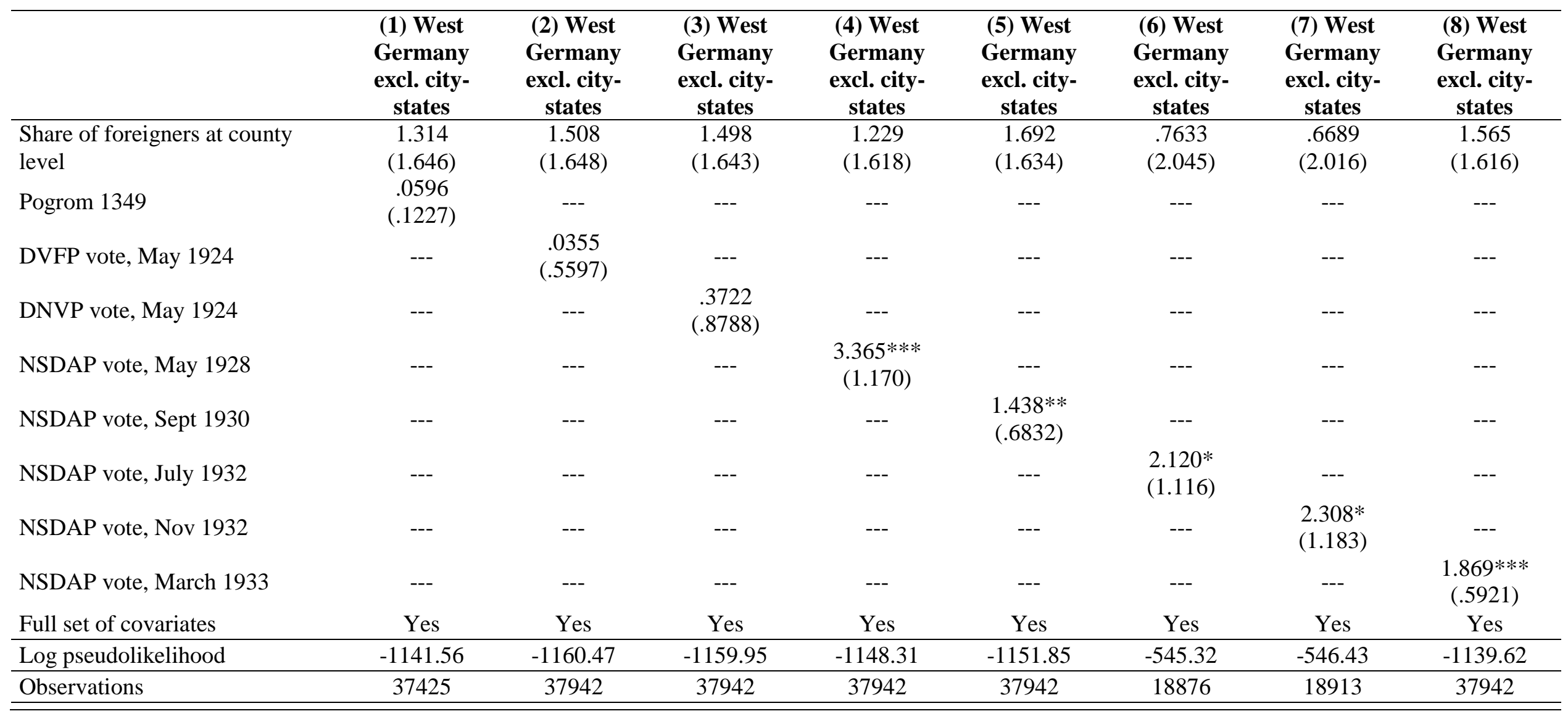

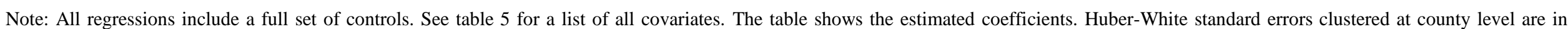

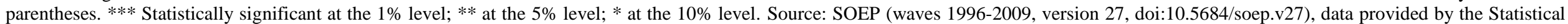
Office of Rhineland-Palatinate, and data provided by Voigtländer and Voth (2012a), own calculations. 
Table 8: IV-Probit Estimates - Controlling for Cultural Traits

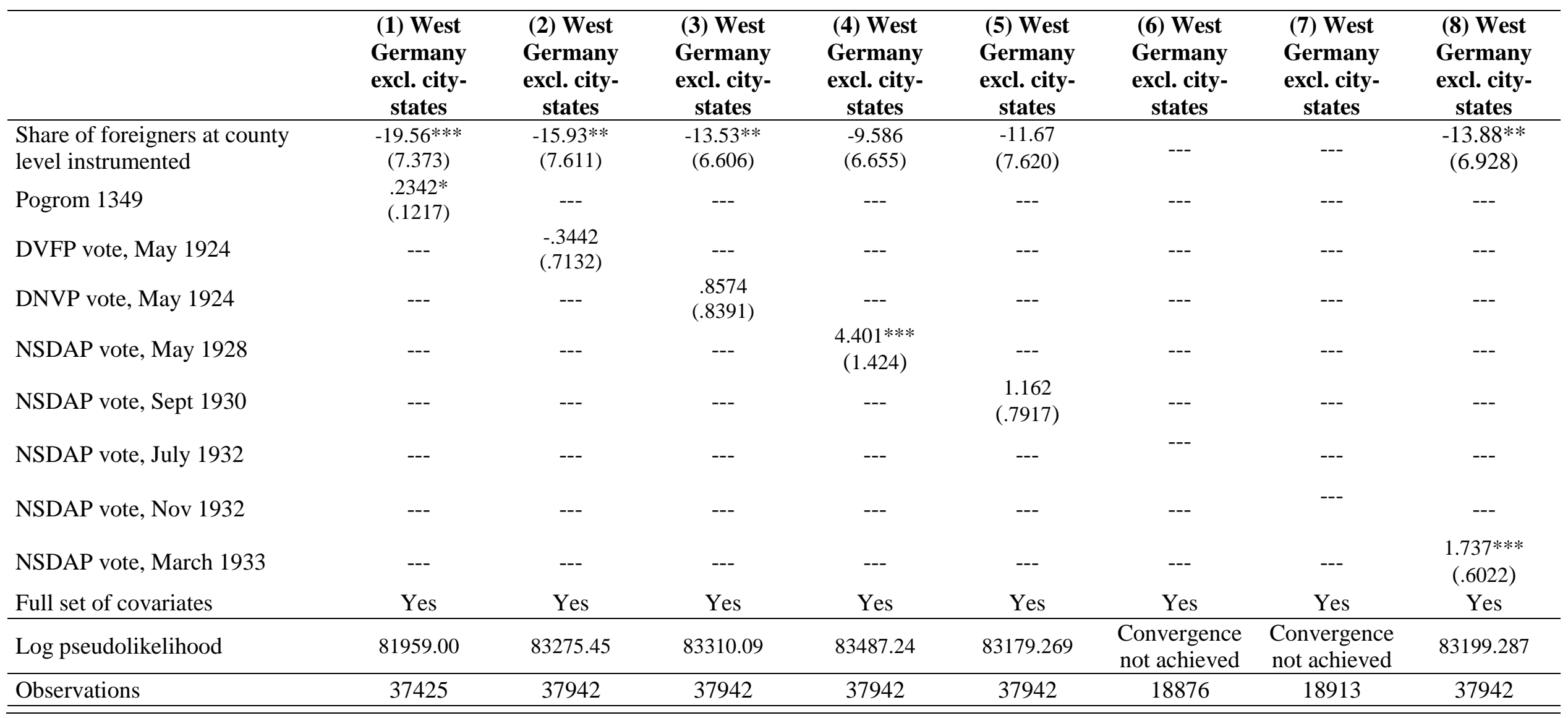

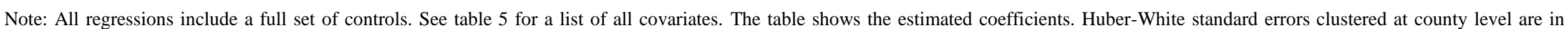

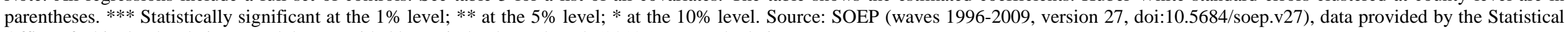
Office of Rhineland-Palatinate, and data provided by Voigtländer and Voth (2012a), own calculations. 
Table 9: Probit- and IV-Estimates - By Subsamples based on Education

\begin{tabular}{|c|c|c|c|}
\hline & \multicolumn{3}{|c|}{ Probit } \\
\hline & $\begin{array}{l}\text { (1) West Germany } \\
\text { excl. city-states } \\
\text { Low Education } \\
\end{array}$ & $\begin{array}{c}\text { (2) West Germany } \\
\text { excl. city-states } \\
\text { Intermediate Education }\end{array}$ & $\begin{array}{l}\text { (3) West Germany } \\
\text { excl. city-states } \\
\text { High Education }\end{array}$ \\
\hline $\begin{array}{l}\text { Share of foreigners at } \\
\text { county level }\end{array}$ & $\begin{array}{c}2.045 \\
(2.346)\end{array}$ & $\begin{array}{c}1.677 \\
(1.893)\end{array}$ & $\begin{array}{c}6.292 \\
(4.135)\end{array}$ \\
\hline Log pseudolikelihood & -313.064 & -967.48 & -114.58 \\
\hline \multirow[t]{3}{*}{ Observations } & 6885 & 25549 & 15075 \\
\hline & & IV & \\
\hline & $\begin{array}{l}\text { (1) West Germany } \\
\text { excl. city-states } \\
\text { Low Education }\end{array}$ & $\begin{array}{c}\text { (2) West Germany } \\
\text { excl. city-states } \\
\text { Intermediate Education }\end{array}$ & $\begin{array}{l}\text { (3) West Germany } \\
\text { excl. city-states } \\
\text { High Education }\end{array}$ \\
\hline $\begin{array}{l}\text { Share of foreigners at } \\
\text { county level instrumented }\end{array}$ & $\begin{array}{c}1.171 \\
(8.833)\end{array}$ & $\begin{array}{c}-14.87 * * \\
(6.694)\end{array}$ & $\begin{array}{c}-13.56^{*} \\
(7.231)\end{array}$ \\
\hline Rho & $\begin{array}{c}.0229 \\
(.2174)\end{array}$ & $\begin{array}{l}.4877 * * \\
(.2110)\end{array}$ & $\begin{array}{l}.6427 * * \\
(.3251)\end{array}$ \\
\hline F-Value & $21.82 * * *$ & $14.01 * * *$ & $19.43 * * *$ \\
\hline Log pseudolikelihood & 15640.66 & 56424.45 & 32081.73 \\
\hline Observations & 6885 & 25549 & 15075 \\
\hline
\end{tabular}

Note: All regressions include a full set of controls. See table 4 for a list of all covariates. The table shows the estimated coefficients. Huber-White standard errors clustered at county level are in parentheses. *** Statistically significant at the $1 \%$ level; ** at the 5\% level; * at the $10 \%$ level. $\mathrm{F}$ Value obtained from first-stage regression. Source: SOEP (waves 1996-2009, version 27, doi:10.5684/soep.v27), data provided by the Statistical Office of Rhineland-Palatinate, own calculations. 


\section{References}

Aldashev, Alisher, Johannes Gernandt and Stephan L. Thomsen. 2012. "The ImmigrantNative Wage Gap in Germany", Journal of Economics and Statistics (Jahrbuecher fuer Nationaloekonomie und Statistik) 232(5): 490-517.

Amemiya, Takeshi. 1978. "The estimation of a simultaneous equation generalized probit model", Econometrica 46: 1193-1205.

Arzheimer, Kai and Elisabeth Carter (2006): "Political Opportunity Structures and RightWing Extremist Party Success", European Journal of Political Research, 45: 419443.

Backer, Susann. 2000. "Right-wing extremism in unified Germany", in: Hainsworth, Paul (eds) The Politics of the Extreme Right: From the Margins to the Mainstream, Pinter, London and New York: 87-120.

Bell, Brian, Stephen Machin and Francesco Fasani. 2010. "Crime and Immigration: Evidence from Large Immigrant Waves”, CEP Discussion Paper No. 984.

Bound, John, David Jaeger and Regina Baker. 1995. "Problems with Instrumental Variables Estimation When the Correlation Between the Instruments and the Endogenous Explanatory Variable is Weak", Journal of the American Statistical Association 90: 443-450.

Card, David, Christian Dustmann, and Ian Preston 2012. "Immigration, Wages, and Compositional Amenities", Journal of the European Economic Association, 10:78-119.

Cornelißen, Thomas and Uwe Jirjahn. 2012. "September 11th and the Earnings of Muslims in Germany - The Moderating Role of Educationand Firm Size", Journal of Economic Behavior and Organization 81: 490-504.

Dill, Verena and Uwe Jirjahn. 2011. "Ethnic Residential Segregation and Immigrants' Perceptions of Discrimination in West Germany", Research Papers in Economics, No. $10 / 11$.

Dill, Verena, Georgi Tsertsvadze and Uwe Jirjahn. 2011. "Residential Segregation and Immigrants' Satisfaction with the Neighborhood in Germany", Research Papers in Economics, No. 8/11.

Dustmann, Christian, Francesca Fabbri and Ian Preston. 2011. "Racial Harassment, Ethnic Concentration, and Economic Conditions", Scandinavian Journal of Economics, 113(3), 689-711.

Dustmann, Christian and Ian Preston. 2001. "Attitudes to Ethnic Minorities, Ethnic Context and Location Decisions", Economic Journal 111: 353-373. 
Falk, Armin, Andreas Kuhn and Josef Zweimüller. 2011. "Unemployment and Right-Wing Extremist Crime”, Scandinavian Journal of Economics 113(2): 260-285.

Fertig, Michael and Christoph M. Schmidt. 2011. "Attitudes towards foreigners and Jews in Germany: identifying the determinants of xenophobia in a large opinion survey", Review of Economics of the Household 9: 99-128.

Fossett, Mark A. and Jill K. Kiecolt. 1989. "The relative size of minority populations and white racial attitudes", Social Science Quarterly 70: 820-835.

Funke, Manfred. 1994. Rechtsextremismus in Deutschland - historische Entwicklung und aktuelle Bedeutung. Melle Knoth: Berlin.

Gang, Ira N. and Francisco L. Rivera-Batiz. 1994. "Unemployment and Attitudes Toward Foreigners in Germany", in G. Steinmann and R. Urich (eds), Economic Consequences of Immigration in Germany, Germany: Physica-Verlag, 121-154.

Gang, Ira N., Francisco L. Rivera-Batiz and Myeong-Su Yun. 2002. "Economic Strain, Ethnic Concentration and Attitudes Towards Foreigners in the European Union", IZA DP No. 578.

Glaser, James M. 1994. "Back to the Black Belt: Racial Environment and White Racial Attitudes in the South", Journal of Politics 56: 21-41.

Janus, Alexander L. 2010. "The Influence of Social Desirability Pressures on Expressed Immigration Attitudes", Social Science Quarterly 91(4): 928-946.

Krueger, Alan B. and Jörn-Steffen Pischke. 1997. "A Statistical Analysis of Crime Against Foreigners in Unified Germany”, Journal of Human Resources 32: 182-209.

Lennox, Clive. 2012. "Racial integration, ethnic diversity, and prejudice: empirical evidence from a study of the British National Party", Oxford Economic Papers 64: 395-416.

Lubbers, Marcel and Peer Scheepers. 2001. "Explaining the Trend in Extreme Right-Wing Voting: Germany 1989-1998”, European Sociological Review 17: 431-449.

Mayda, Anna Maria. 2006. "Who is against immigration? A cross-country investigation of individual attitudes toward immigrants", Review of Economics and Statistics 88: 510-530.

Oliver, Eric J. and Tali Mendelberg. 2000. "Reconsidering the Environmental Determinants of White Racial Attitudes", American Journal of Political Science, Vol. 44 (3), p. 574-589.

Ortega, Francesc and Javier G. Polavieja. 2012. "Labor-market exposure as a determinant of attitudes toward immigration", Labour Economics 19: 298-311. 
Pettigrew, Thomas F. 1998. "Intergroup contact theory", Annual Review of Psychology 49: 65-85.

Quillian, Lincoln. 1995. "Prejudice as a Response to Perceived Group Threat: Population Composition and Anti-Immigrant and Racial Prejudice in Europe." American Sociological Review 60: 586-611.

Rivers, Douglas and Quang H. Vuong. 1988. "Limited information estimators and exogeneity tests for simultaneous probit models", Journal of Econometrics 39: 347-366.

Rothbart, Myron and Oliver P. John. 1993. "Intergroup Relations and Stereotype Change: A Socio Cognitive Analysis and Some Longitudinal Findings", In P. M. Sniderman, P. E. Tetlock, and E. G. Carmines (Eds.). Prejudice, Politics, and the American Dilemma. Stanford University Press.

Rotte, Ralph and Martin Steininger. 2008. "Crime, Unemployment and Xenophobia? An Ecological Analsysis of Right-Wing Election Results in Hamburg, 1986-2005", IZA DP No. 3779.

Schüller, Simone. 2012. "The Effects of 9/11 on Attitudes Toward Immigration and the Moderating Role of Education", IZA Discussion Paper 7052.

Sherif, Muzafer and Carolyn W. Sherif. 1953. "Groups in Harmony and Tension", New York: Harper.

Siedler, Thomas. 2011. "Family and Politics: Does Parental Unemployment Cause RightWing Extremism", Journal of the Royal Statistical Society: Series A. 174(3), 737758 .

Taylor, Marylee C. 1998. "How White Attitudes Vary with the Racial Composition of Local Populations: Numbers Count", American Sociological Review 63: 512-535.

Voigtländer, Nico and Hans-Joachim Voth. 2012a. "Persecution Perpetuated: The Medieval Origins of Anti-Semitic Violence in Nazi Germany", Quarterly Journal of Economics 127(3): 1-54.

Voigtländer, Nico and Hans-Joachim Voth. 2012b. “(Re-) Shaping Hatred: Anti-Semitic Attitudes in Germany, 1890-2006“, CEPR DP 8935.

Wagner, Gert G., Joachim R. Frick, and Jürgen Schupp. 2007. "The German SocioEconomic Panel Study (SOEP) - Scope, Evolution and Enhancements", Schmollers Jahrbuch 127(1): 139-169

Weil, Frederick D. 1985. "The Variable Effects of Education on Liberal Attitudes: A ComparativeHistorical Analysis of Anti-Semitism Using Public Opinion Survey Data”, American Sociological Review, Volume 50(4): 458-474. 
Weins, Cornelia. 2011. „Gruppenbedrohung oder Kontakt? Ausländeranteile, Arbeitslosigkeit und Vorurteile in Deutschland“, Kölner Zeitschrift für Soziologie und Sozialpsychologie 63: 481-499. 


\section{Endnotes}

${ }^{1}$ For more information about the series of killings of small-business people in Germany see, for example, “The True Threat to Integration in Germany", Judy Dempsey, The New York Times, August 2012, http://www.nytimes.com/2012/08/07/world/europe/07ihtletter07 .html.

${ }^{2}$ Using the German General Social Value Survey, in a recent published working paper Voigtländer and Voth (2012b) find that historical voting patterns from the 1920s/30s are good predictors of current xenophobic attitudes.

${ }^{3}$ The list of parties that are nominated for the 2009 Bundestag election is published by the Federal Returning Officer of Germany.

${ }^{4}$ For example, Dustmann and Preston (2001) use prejudice against minorities and attitudes to certain issues (interethnic marriage, ethnic minority superiors at work, race discrimination legislation) as dependent variables, whereas Krueger and Pischke (1997) use right-wing motivated crime. The tendency to vote for an extreme right-wing party considered in this paper is located in between subtle measures and violent outbreaks of hostility. However, results based on a specific measure of hostility may not be applied to other measures of hostility (Dustmann et al. 2011).

${ }^{5}$ I am very grateful to Nico Voigtländer and Hans-Joachim Voth who kindly shared their data.

${ }^{6}$ Foreigners have a lower educational level on average and are overrepresented in the lowskilled segment of the labor market. Moreover, it can be shown that foreigners are more likely to have a job mismatch since their educational degrees obtained abroad are valued 
less on the German labor market and thus foreigners tend to work more frequently in the unskilled or semi-skilled segment than comparable German citizens (Aldashev et al. 2012).

${ }^{7}$ For an overview of the political parties with special reference to right-wing extremism in Germany, see Rotte and Steininger (2008) or Backer (2000).

${ }^{8}$ In the period from 2005 to 2009 several county property reforms were implemented across Germany enlarging the area of political counties. One of the main purposes of these reforms was to extend the territorial catchment area for institutions in order to increase efficiency.

${ }^{9}$ I am thankful to the staff of the DIW for their support in carrying out this analysis via "soepremote".

10 The SOEP also covers a large sample of ethnic Germans, sometimes referred to as "resettlers". They are non-German citizens who consider themselves as Germans which is based on the fact that their ancestors were German. After 1990 many ethnic Germans from the Eastern Bloc used the Law of Return to immigrate to Germany. The Law of Return grants the German citizenship to all ethnic Germans who provide evidence of their German ethnic origin. Even though, ethnic Germans are German citizens, this group of respondents experienced a significantly different history until immigrating to Germany compared to German natives. That is why, it was necessary to exclude them from the sample used here.

${ }^{11}$ Like previous empirical studies that use the SOEP, I cannot rule out that the moderating role of education found here is the result of a perceived social desirability response bias (e.g. Schüller 2012). It has been shown that high educated individuals react more sensitive to survey questions which ask to reveal attitudes toward immigration compared to loweducated (Janus 2010). 